\title{
Does Price Fixing Benefit Corporate Managers?
}

\author{
Tanja Artiga González, ${ }^{a}$ Markus Schmid, ${ }^{b}$ and David Yermack ${ }^{c, \#}$
}

September 2017

\begin{abstract}
We study the effects of cartel participation on top corporate managers. Although a strong public interest exists in regulating price fixing, we find little evidence that either corporate governance or the legal system holds managers of cartel firms accountable. Instead, managers of cartel firms enjoy greater job security, receive higher cash bonuses, and extract more ex post compensation through timely exercise of stock options. Legal sanctions against individual managers are infrequent, with enforcement actions focused on corporations rather than their officers. Managers appear to use concealment strategies actively to limit detection of cartel membership by their boards and auditors.
\end{abstract}

JEL Classification: D43, G34, K42, L40, M43.

Keywords: Price fixing, corporate governance, executive compensation.

We are grateful to Tim Adam, Martin Bugeja, Mike Burkhart, John Core, Ettore Croci, Daniel Ferreira, Paul Gilgen, William Greene, Robert Guerrero, John Hund, Simi Kedia, Peter Limbach, Daniel Metzger, Alexandra Niessen-Ruenzi, Shiva Rajgopal, Daniel Sokol, Suraj Srinivasan, and seminar participants at Catholic University of Milan, Cyprus University of Technology, University of Melbourne, New York University, UT Austin, University of Queensland, University of Technology Sydney, Warwick Business School, University of Western Australia, the Edinburgh Corporate Finance Conference, the Swiss Finance Association Meeting in Zurich, and the German Finance Association Meeting in Wuppertal for helpful comments and suggestions. We thank John Connor for generously providing his extensive PIC dataset of worldwide cartels and Ronald Masulis for generously providing his dataset of foreign independent directors. Part of this research was completed when David Yermack was a visiting professor at Erasmus University Rotterdam and Tanja Artiga González and Markus Schmid were visiting researchers at NYU Stern School of Business. Financial support from the Swiss National Science Foundation (SNSF) and the German Academic Exchange Service (DAAD) is gratefully acknowledged.

${ }^{a}$ VU Amsterdam.

${ }^{b}$ Swiss Institute of Banking and Finance, University of St. Gallen.

${ }^{c}$ Stern School of Business, New York University and National Bureau of Economic Research.

\#Corresponding author. Address: Department of Finance, NYU Stern School of Business, 44 West $4^{\text {th }}$ Street, Suite 9-160, New York, NY 10012. Phone: $+1-212-998-0357$. E-mail addresses: t.artigagonzalez@vu.nl, markus.schmid@unisg.ch, and dyermack@stern.nyu.edu. 


\section{Does Price Fixing Benefit Corporate Managers?}

\section{Introduction}

Price fixing by companies that participate in cartels is against the law, and it imposes significant costs on consumers in the U.S. and around the world. While the full extent of price fixing is not known, economists have estimated affected sales at about $\$ 51$ trillion and cartel overcharges at between $\$ 1.5$ and 4.6 trillion worldwide (Connor, 2016). In the U.S., both federal regulators in the Department of Justice and attorneys general in the 50 states can bring criminal sanctions for price fixing, and some high-profile cases have become iconic examples of corporate malfeasance. Perhaps the best-known example in recent years was the Archer Daniels Midland conspiracy with Japanese and Korean firms to fix prices in the lysine market in the mid1990s, which led to a $\$ 100$ million fine for ADM and the imprisonment of three of its top managers. Other well-known episodes include the vitamin cartels and LIBOR interest rate cartel, each of which lasted for lengthy periods before being uncovered.

When price fixing is uncovered, should the scheme be viewed as a failure of corporate governance? While moral and legal arguments against price fixing are clear, the economic case against cartel membership seems decidedly ambiguous. Cartelists that are caught will incur direct costs from fines, penalties, and attorneys' fees, and they may face larger reputational damage that affects their standing with consumers and regulators. At the same time, companies earn higher profits during the time when a cartel operates undetected, and research suggests that 
profits can be so high and detection rates so low that the economic incentive for firms to fix prices is strong. Connor and Helmers (2007) estimate that only $10 \%$ to $30 \%$ of all price-fixing conspiracies are ever discovered and that worldwide corporate penalties for firms participating in cartels are a relatively modest $\$ 2$ billion per year, with approximately $60 \%$ due to government fines (mainly from U.S. and European regulators) and 40\% paid to settle private litigation. Moreover, Levenstein and Suslow (2006), Bolotova (2009), and Connor (2010) show that cartels are generally beneficial even to those firms that are apprehended, as fines are generally smaller than estimated overcharges to consumers.

This paper studies the experience of top corporate managers in U.S. firms that are convicted of cartel behavior. Prior research indicates that decisions to join cartels are typically taken by a firm's very top managers and then implemented by the intermediate management (Harrington, 2006; Connor, 2014). We use the Private International Cartel dataset created by John Connor and described in detail in Connor (2014) to identify 248 listed U.S. firms that are successfully prosecuted for taking part in "hard-core cartels," a description used by the Antitrust Division of the U.S. Department of Justice for agreements (contracts, deals, coordinated bidding, etc.) that companies form with the intent to control market prices or restrict industry supply (or both).

The managers in our cartel firms appear to benefit in several ways from cartel participation. These firms' top managers extract higher ex-post compensation than managers in a control sample because of opportune exercises of executive stock options during the cartel period. Cartel firms' managers also receive more of their compensation in cash bonuses, a less risky form of pay than equity, and these bonuses are likely increased indirectly by higher profits during the cartel period. CEO turnover regressions show that cartel firms' CEOs have greater 
job security with respect to both forced and voluntary turnover. At the same time, our data show that relatively few cartel firm managers end up as criminal defendants or are ever required to pay fines or disgorge compensation gains. Collectively, these results imply that cartel participation is very attractive for top corporate managers, at least in financial and job security terms.

If a strong public interest exists in controlling cartels, one might argue that the lack of consequences for corporate managers may represent a corporate governance failure at the firms involved. In recent years boards have faced great shareholder pressure to act against a range of managerial misbehavior such as insider trading, excessive financial risk-taking, and fraudulent disclosures and marketing practices. In contrast, we see little evidence of shareholder protest against price fixing, and even less interest by boards in acting against managers who lead their firms into cartels.

Why do boards appear to ignore or tolerate price fixing? One reason may be that managers successfully conceal these conspiracies from their own boards and auditors at the same time that they are hiding them from consumers and regulators. In Section 4 of our paper, we find evidence of a number of strategies that could result from top managers' influence over corporate governance. When the CEO position becomes vacant, firms tend to groom and promote internal successors rather than recruit new CEOs from outside the firm. Vacant board seats tend to be left open for longer periods, and when new directors are recruited, they tend to be less disposed to active monitoring due to residence in foreign countries or having high social ties with corporate management. Auditor rotation occurs less frequently in cartel firms.

The remainder of this paper is organized as follows. Section 2 contains a description of the dataset and control sample. Section 3 presents an analysis of the incentives and consequences for managers of cartel firms in the areas of executive compensation, legal 
sanctions, and CEO replacement. Section 4 presents an analysis of concealment strategies implemented through corporate governance channels. Section 5 concludes the paper.

\section{Sample selection and data description}

\subsection{Cartel firms}

We use the U.S. firms included in a recently extended and updated version of John Connor's (2010) hand collected Private International Cartel dataset, as described in Connor (2014), which covers private cartels discovered, disclosed, and sanctioned by regulators around the world between January 1990 and December 2014. This dataset has been used in other recent empirical studies on cartels including Dong, Massa, and Zaldokas (2016) and Campello, Ferrés, and Ormazabal (2016). The dataset omits cartels protected by sovereignty or multilateral treaties, such as OPEC, as well as those for which no sanctions were imposed within five years of the authorities' discovery. A total of 1,291 cartels and 8,302 participants appear in the dataset. In certain cases firms are sanctioned anonymously. Many companies are repeat offenders and participate in multiple cartels. The median cartel involves five companies and lasts six years before discovery by regulators; the maximum values are considerably higher, with some cartels lasting for decades and involving dozens of companies or more. ${ }^{1}$

The dataset includes each firm's name, country of incorporation, the market(s) and continent(s) where collusion took place, the duration of the collusive agreement, and if known, the fines imposed, leniency granted by regulators, and estimated overcharges to consumers. Information is collected mainly from court filings, documents, reports, and press releases from the antitrust authorities in different countries, as well as newspaper and magazine articles

\footnotetext{
${ }^{1}$ Connor (2010) reports one case of more than 2,000 unnamed construction companies accused of price fixing by authorities in the Netherlands.
} 
retrieved through search engines like Factiva or Lexis-Nexis. The database generally includes more observations in recent years. We do not know whether this pattern occurs due to better enforcement, more disclosure by regulators, more coverage by the press, or a greater tendency by companies to collude in price fixing or bid rigging. European companies comprise the majority of observations in the dataset, although many cartels are global and involve multinational firms operating on several continents.

To select our sample, we begin with 1,153 U.S. companies included in the international dataset. We only keep firms covered by Standard \& Poor's Compustat during our sample period 1985-2014, which substantially reduces the sample size to 248 firms that are involved in a total of 327 conspiracies (certain conspiracies concern more than one sample company). We obtain data for 2,414 cartel company-year observations (including part-years) for these 248 firms over the $1985-2014$ period, with 89 of the 248 companies participating in more than one cartel. The mean (median) cartel period is 7.57 (6) years for our sample. JPMorgan Chase \& Co. is involved in 21 individual cartels, the most of any company in the sample, followed by Exxon Mobil Corp. with 16.

We augment the financial statement data from Compustat for our 248 firms with information from other financial and governance sources, including the Center for Research in Securities Prices (CRSP) stock price database, the ISS (formerly RiskMetrics) Governance and Directors databases, BoardEx, Standard \& Poor's ExecuComp database, and the Audit Analytics database. Missing values in these datasets reduce the observations available for some of our analysis below. 


\subsection{Control sample of matched firms}

We construct a control sample of comparable companies matched on size and industry. For every cartelist, we identify the Compustat firms with the same two-digit primary SIC code in the year before the first collusive agreement starts. We then take the five firms with firm size, measured by total assets, closest to the size of the cartel firm. If a conspiracy was already active in 1985, the beginning of our sample period, we use the first cartel firm-year in our sample to form the corresponding control group. No cartel firm is permitted also to enter the control sample. If a non-cartel firm qualifies as a control firm for more than one cartel firm, we include it in the control samples for both, although we include each unique firm-year observation only once. Our final sample includes 2,414 cartel firm-years for 248 offending companies and a control group of 6,915 firm-years for 833 companies matched on size and industry. This represents all cartel firm-years of the cartel firms and the respective matched firm-years of the control firms. Some control firms are delisted prior to the end of a cartel, and in these cases we do not replace them. A handful of cartels occur in business units that are spun off into independent companies by their parents, at some point after the initiation of the cartel. In these cases we track the parent up to the year of the spinoff, and then track the spinoff afterwards; although these will appear as two unique cartel firms in our sample, we do not change the original control sample midstream. We cannot rule out the possibility that the control sample includes firms that participated in a cartel and avoided detection. However, including hidden cartelists among our control firms would reduce the statistical power of our tests and render our estimates more conservative than the true underlying effects.

Table 1, Panel A presents summary statistics for our cartel and control firms as measured in the matching year, including the means, medians, and standard deviations across these two 
subsamples. The summary statistics show that, at the time of the matching, cartel firms do not differ much from our control group. The only statistically significant difference between cartel and control firms is firm size, and, related to size, the number of business segments. Cartelists often are the largest firms in their industries, which seems logical since substantial market power would be required to fix prices successfully, but the size primacy of some cartelists creates an issue in attempting to construct an appropriate control sample. Due to this pattern, we include a measure of firm size in virtually all regressions, generally using an estimate of total enterprise value equal to the log of market value of equity plus book value of debt.

To address further the difference in firm size across the two samples, we experiment with a number of alternative control samples, including a control group in which we require all control firms to have total assets within $+/-50 \%$ of the cartel firm, and three variations of propensity score matching. A description of these alternative control samples and a replication of our main results using these four alternative matching procedures are explained in the Appendix and reported in Table A1, and this analysis finds that other matching procedures make little difference in the size and significance of the regression estimates reported in the paper.

Table 1, Panel B, includes descriptive statistics for all variables measured over all observations used in our analysis below. Our regressions generally include numerous lead and lag years for the period surround the years of cartel membership, which accounts for the relatively large numbers of observations in Panel B. However, we generally cannot include all of our cartel and control sample observations in our regression analysis below, because some databases do not cover all of our firms (for example, ExecuComp tracks only 1,500 companies from Compustat), and nearly all databases except Compustat have a later coverage start date than 
1985, which is our first year of cartel data. In our tables we indicate the number of firms and observations used in the analysis for both the cartel and control samples.

\subsection{Cartel statistics}

Table 2, Panel A, presents descriptive statistics about the cartels and cartel firms in our sample. The 248 listed U.S. cartel firms in our sample participate in 327 different cartels. In total our sample includes 634 firm-cartel participations as in many cartels more than one of our sample firms participate (on average our sample firms are identified as members of 2.46 cartels). In 309 of the 634 cartel participations in our sample, a subsidiary was penalized and in 194 cases the subsidiary was a non-U.S. firm. At the cartel level, we find the mean (median) number of firms participating in the cartels covered by our sample to be 8.05 (6), with a minimum of two and a maximum of 55. The average (median) duration of the 327 cartels in our sample is 7.57 (6) years. To find out more about cartel participants, for the 327 cartels in our sample, we match the names of all participating companies to the Compustat and Compustat Global databases and identify public firms included in these databases. On average, $73 \%$ of the firms in a cartel are public, ranging from $6 \%$ to $100 \%$.

Panel B reports information on the place of collusion and the lead jurisdictions investigating the cartels in our sample. The majority of cartel agreements in our sample concerned global product markets ( 80 cartels involving 162 sample firms) or the North American market (76 cartels involving 203 sample firms). This is also mirrored in the lead jurisdictions handling the cases. The top lead jurisdiction is the United States investigating 89 cartels (either by the Department of Justice or private firms), followed by the European Commission with 39 
cartels identified. These data are of course influenced by our sample requirement that each cartel include at least one U.S. public firm that is covered by Compustat.

Connor's Private International Cartel dataset also provides information about the estimated economic harm caused by each cartel and the sanctions against firms and their managers. We summarize this information for the firms in our sample in Panel C of Table 2. Based on Connor's estimates, the median affected commerce per cartel is about $\$ 4.45$ billion. ${ }^{2}$ The consumer overcharges have a mean value of $\$ 7.84$ billion, a median of $\$ 0.44$ billion, and a maximum of $\$ 245.60$ billion, indicating that some of the cartels extract significant economic rents from the retail market. The average fine paid per cartel is $\$ 279.72$ million with a median value of $\$ 21.95$ million. The average fine paid by each cartel member in our sample is $\$ 58.90$ million with a median value of $\$ 4.62$ million. ${ }^{3}$ Hence, our descriptive evidence suggests that fines are substantially smaller than estimated overcharges, rendering cartels highly profitable ventures net of enforcement costs (if any). Levenstein and Suslow (2006), Bolotova (2009), and Connor (2010) show that cartels are generally beneficial even to those firms that are apprehended, as fines are generally smaller than estimated overcharges to consumers and many are never discovered by authorities.

\section{Personal consequences for managers of cartel firms}

Our analysis below examines aspects of the careers of company CEOs and directors, including their selection, compensation, and removal, under the premise that top management is complicit in (or at least aware of) many cartel conspiracies while the board in general is not. A

\footnotetext{
2 The mean of $\$ 6,578$ billion is mostly due to the LIBOR cartel in which 27 banks participated and was estimated to have affected total commerce of $\$ 600$ trillion.

${ }^{3}$ Some of these values are estimates as the effective fines are not publicly disclosed. In some instances, due to leniency, nolo contendere, or cease-and-desist pleas, lower or even no fines are imposed. This is especially true for the early years in our sample.
} 
review of recent news stories confirms that often these cases implicate division presidents, CEOs, and other members of top management, who are identified as knowing about a scheme even if they are not charged as defendants. ${ }^{4}$ However, only rarely do cases implicate outside members of a board of directors.

\subsection{Executive compensation}

In this subsection we examine financial gains to the top managers of cartel firms. In untabulated regression analysis, we do not find cartel executives earning significantly more $e x$ ante compensation than their counterparts in the control sample, when compensation is valued as of the award date and the regression model includes controls for firm size, profitability, industry, CEO tenure, and other standard variables. However, one could easily argue that cartels increase management pay indirectly through their influence upon these variables, since cartel firms may grow larger, earn higher profits, and retain their management teams longer (a result we document below). For similar reasons, the value of equity pay could increase ex post for cartel managers relative to its award date value.

We believe our more important results, each of which is consistent with rent extraction by cartel firms' CEOs and top executives, appear in the analysis in Tables 3 and 4. Table 3 studies the provident timing of stock option exercises by managers, who are shown to increase their rates of exercise during the cartel period when the firm's stock price is likely inflated by successful price fixing in its product markets. Table 4 examines the mix of pay and finds a tendency of cartel firms to pay more compensation in the form of accounting bonuses, which are less risky to

\footnotetext{
${ }^{4}$ For example, in February 2014 the CEO of Sea Star Line received a five-year prison sentence in a price fixing case in which the CEO of another shipper was also convicted. In 2013 several candy companies, including Hershey and Nestle, pleaded guilty to price fixing charges in Canada in a case that implicated the division presidents of each company. In 2013 Apple Inc. was convicted of orchestrating a price fixing scheme in the eBook market. Although he was not charged, a company Sr. Vice President was implicated in the case, and evidence at trial indicated that the late CEO Steve Jobs likely had knowledge of the scheme.
} 
the managers particularly if they conspire with other firms to maintain a high level of profitability in the industry.

We use two types of models in these tables and most of the other analysis below. In Panel A of each table, we report estimates from pooled regressions of different board variables on an indicator that equals one for years of cartel participation, with additional regression controls included. The sample for these regressions includes all active cartel years for the cartel firms and the relevant matched control sample observations. Panel B reports estimates from a within-firm analysis in which the cartel firm indicator is replaced by three binary variables indicating the time before the cartel, during the cartel, and after the cartel. This framework is similar to that used by Kedia and Philippon (2009) in their study of how firms and their managers behave during periods of financial fraud. The Before variable encompasses a five-year period starting seven years before and ending two years before the cartel conspiracy was determined to have started, and the variable After includes a five-year period after the end of the cartel, starting two years after the end of the cartel as determined by authorities. To account for uncertainty in the beginning and end dates of the cartel, we exclude the two years before and after the cartel. The sample in Panel B of each table includes the Before, During, and After observations for all cartel firms as well as the complete history of matched control firms (as available for our sample period). All of the control variables from the Panel A regressions are carried over to the models in Panel B, but we do not tabulate their estimates in order to save space.

Kedia and Philippon (2009), studying a sample of firms that commit financial fraud, document an abnormally rapid exercise of in-the-money stock options by managers during the fraud period. The obvious interpretation of their result is that managers attempt to withdraw 
equity compensation from the company when the per-share price is inflated above its likely longterm value. We investigate stock option exercises by managers of cartel firms using the same approach. Cartel firms' managers should wish to withdraw their compensation before regulators discover the scheme. In addition, rapid stock option exercises may play a diversionary role, by communicating to outsiders that the managers do not expect future abnormal increases in the stock

In Table 3 we present an analysis of stock option exercises by the CEOs (columns 1 and 2) and the top five named executives (columns 3 and 4) in our cartel firms compared to the executives in our control sample. Our data source for option exercises is the S\&P ExecuComp database, and relying on this database greatly reduces our sample size since it covers only about one-quarter of the companies on Compustat. Our regression specifications follow those reported by Kedia and Philippon (2009). We use two dependent variables: (i) the dollar value of option profits realized by managers, divided by the total amount by which vested options are in-themoney (the options' intrinsic value) at the start of the year, and (ii) a more simple calculation of the ratio between number of options exercised and the number that are vested and could theoretically have been exercised, whether in-the-money or not. Control variables include the size of the firm's total inventory of outstanding employee stock options, the exercise rate for all firms in the two-digit SIC industry, Tobin's $Q$, and the firm's stock return in the past year, along with fixed effects for year and industry. The Before variable in the regressions is an indicator that equals one during a five-year period starting seven years before and ending two years before the cartel conspiracy was determined to have started. Similarly, the During indicator variable covers the years that the cartel is active, as subsequently determined by prosecutors, and the indicator After spans a five-year period after the end of the cartel, beginning two years after the final year. 
Results of these cross-sectional tests appear in Panel A of Table 3. In all four models, estimates indicate that managers from cartel firms exercise their stock options more rapidly than managers from firms in the control sample. These patterns of early option exercise could occur for a number of reasons, but they are consistent with an interpretation that managers wish to withdraw their equity compensation before the cartel might be exposed. The estimates appear to be economically large. For example, the mean of the dependent variable in the first column for non-cartel firms is 0.183 . The coefficient estimate of 0.058 in the top left cell of Table 3 indicates that the propensity to exercise options is about 32 percent $(=0.058 / 0.183)$ stronger for CEOs in cartel firms compared to their counterparts in the control sample. The results of the within-firm analysis in Panel B confirm the findings from the cross-sectional analysis. The coefficient on the During variable is significant at the 5\% level across all four columns with none of the Before or After coefficients being statistically significant, indicating that cartel managers exercise their stock options in coincidence with the cartel period, during which their firms' stock prices are likely inflated.

We examine CEOs' and top managers' annual bonuses in Table 4. If cartel firms are able to increase profits and manipulate their timing and growth rates, these firms' managers may be able to obtain higher bonuses. This could occur not only because the firm earns higher returns, but also because the managers could more easily deliver quarterly and annual results tied to accounting performance thresholds commonly found in cash bonus plans (Healy, 1985).

We estimate Tobit models in Table 4 with the dependent variable equal to the CEO's (first three columns) or top five executives' (columns 4-6) bonus divided by total compensation, all as reported by ExecuComp. Control variables in the first and fourth columns follow those used by Leone, $\mathrm{Wu}$, and Zimmerman (2006) in their study of cash compensation. In columns 2 
and 3, we augment the model with CEO-specific variables for age, tenure, and percentage ownership. In column 3, as a robustness test, we follow the approach of Shaw and Zhang (2010) and multiply the control variables in Table 4 by interaction terms for firms with high and low ROA and high and low shareholder returns. In columns 5 and 6, we replace the CEO age by the median age of the top five executives and also replace the percentage change in CEO share ownership by the median change in share ownership by the top five executives. ${ }^{5}$

As shown in the top line of Panel A, the cartel indicator has a significant estimate in the range of +0.02 to +0.03 , implying that cartel firm managers obtain about $2 \%$ to $3 \%$ higher compensation due to increased bonuses. The mean CEO (top executive) bonus as a fraction of total compensation is $0.142(0.140)$ for non-cartel firms, indicating that the estimates for the cartel variable in the top row of Table 4 are economically significant. The results from the within-firm analysis in Panel B confirm those from the cross-sectional analysis in Panel A. The estimates for the During variable are significant at the 5\% level or better across all six columns with coefficients size in the +0.02 to +0.03 range. The estimates for the Before variable are also all positive and significant and of a similar economic magnitude, indicating that cartel managers already obtain higher cash bonuses before a cartel starts. There are two potential explanations for this finding. First, cartel start dates are less precise than end dates, making the differentiation of the before and during periods particularly uncertain. Second, other fraudulent activities may have taken place already before the firm joined the cartel. Consistent with both of these conjectures, the estimates for the After variable have a reversed sign, statistically significant in four of the six columns, indicating a significant change in compensation after detection of the price-fixing conspiracy.

\footnotetext{
${ }^{5}$ Tenure for non-CEO top executives is not reported in ExecuComp. Hence, we omit the tenure-variable from this specification.
} 
In Table 5, we analyze whether cross-sectional patterns exist in our management compensation variables depending on cartel or firm characteristics. We use three alternative partitioning strategies to classify cartel participations into economically more or less meaningful conspiracies. First, we use the number of firms participating in the cartel, assuming that cartels involving more firms are more meaningful, and compare observations for firms in the top tercile of cartel size to the cartel observations for the remaining firms. ${ }^{6}$ Second, we compare conspiracies that take place in the U.S. or globally to those taking place exclusively in other countries. We would expect U.S. or worldwide cartels to be larger and more relevant to U.S. firms. Third, we compare cartel participations in which the parent firm was penalized to those in which a subsidiary was penalized.

We focus our analysis on management compensation, in the belief that the three subsets of cartels that we study should impact the cartel firms more significantly and provide greater profit opportunities for executives. We compute the mean and median values of variables related to option exercises and bonus pay over the years of the cartel duration. We then perform mean comparison tests across the more serious and less serious subsets of cartel firms according to the three partitions described above. The results are reported in Table 5, and they support our hypothesis that managers profit more from more meaningful cartels by accelerating the exercise of stock options even more rapidly and obtaining larger cash bonuses. The differences between the two sub-samples are statistically significant with few exceptions.

Next, we test whether cartel managers are more likely to obtain these compensation benefits if there is weaker investor oversight or if the firm is less transparent. As a measure of

\footnotetext{
6 Other measures of cartel importance are associated with important caveats. Fines depend on both leniency and the jurisdiction, with huge differences in the latter. Affected sales and overcharges are only made public on the cartel level. Unfortunately, there is no natural way to allocate them to the participating firms. Moreover, estimated overcharges are available for only about 50 percent of the sample.
} 
oversight we use the percentage of institutional ownership (e.g., Shleifer and Vishny (1986) and McCahery, Sautner, and Starks (2016)). As a measure of information asymmetry or opaqueness, we use Amihud's (2002) illiquidity measure which is calculated from the ratio of absolute stock returns to dollar volumes. To sort firms into terciles based on the percentage of institutional holdings and the Amihud (2002) illiquidity measure, we calculate mean values over the entire cartel period. In both tests, we compare the top tercile to the remaining observations. As expected, we find that managers of cartel firms with less institutional ownership and managers of more opaque cartel firms exercise more options to profit from the cartel and also obtain a significantly larger fraction of total compensation from cash bonuses.

\subsection{CEO replacement}

Controlling for performance and other relevant factors, we expect cartel firms to exhibit less CEO turnover than other companies, since it should be risky for the firm to recruit a successor and entrust that person with the continuation of an ongoing conspiracy. Similarly to compensation, we also expect cartel managers to benefit indirectly by increasing their job security if price fixing enables them to improve company performance.

Table 6 presents estimates from a probit model in which we study CEO replacement in cartel companies. In the first column of Panel A, we model all CEO replacements as a function of standard control variables such as age, tenure, stock performance, and industry and year fixed effects. Other control variables for this model come from the study of forced CEO turnover by Parrino, Sias, and Starks (2003). Estimates for this model have the expected signs and significance - for instance, CEO replacement occurs less often when a firm performs well and when the CEO is younger. The model also includes an indicator for cartel membership. As 
expected, it has a negative estimate and is statistically significant at the 10 percent level. The marginal effect of this estimate is -0.041 , which is economically meaningful compared to the non-cartel firms' turnover frequency of 14.1 percent. For the subsamples of forced and voluntary turnover in columns 2 and 3, the marginal effects are estimated as -0.014 and -0.025 , respectively. However, the within-firm analysis in Panel B does not show a clear pattern of CEO turnover for the time before, during, and after the cartel. As expected we find an inverse relation between turnover and performance, as measured by the prior year's abnormal stock return, for cases of forced turnover only. An interaction term between the cartel indicator and the company's abnormal stock performance does not have a significant estimate in any of the three models, implying that the performance-turnover relation operates independently of cartel participation.

In the second column of Table 6 , we restrict the dependent variable to cases of forced CEO turnover, using data from Peters and Wagner (2014) and Jenter and Kanaan (2015). In this model, the estimate for the cartel indicator strengthens. The variable for abnormal stock performance becomes strongly negative and more significant than in the model for all turnover. In the third column, the cases of voluntary CEO turnover also exhibit a statistically significant, albeit weaker, association with cartel membership. The results indicate that cartel CEOs have more performance-related job security than their counterparts in the control sample and also tend to leave their jobs voluntarily less often.

\subsection{Legal sanctions}

Strikingly, very few corporate managers are held accountable by prosecutors for their firms' participation in cartels. Our data source provides the names of indicted individual 
managers in each cartel firm, but in most cases no defendants are personally named as often regulators sanction only a firm and not its executives. ${ }^{7}$ A total of 77 individual defendants from 31 cartel firms in our sample are indicted. Given that our sample covers 248 companies, each of which has numerous managers and directors who likely knew of the scheme, we conclude that the very large majority of managers are either undiscovered or undisciplined by regulators.

We use research databases to learn more about the 77 managers who become defendants. The names of three of these 77 are concealed, presumably due to plea bargains, and we collect employment information for the remaining 74 individuals using BoardEx, proxy statements, and LexisNexis, and Google searches. The 74 identified executives are associated with 33 cartel participations by 30 different companies, and 62 (or about 84\%) are division or regional managers. A further seven are regular employees or low-ranked managers. Few top managers are named, as just three executive board members (one of them an executive director) and one single outside director are indicted. When aggregating the data to the cartel participation level, in six of the seven cases in which a low-ranking employee was indicted, at least a divisional or regional manager was also indicted.

Information on prison sentences is often not disclosed. The only two jurisdictions that in general publicly disclose prison sentences are the U.S. and Canada. However, even in these two countries many convicted individuals' identities are hidden, mostly because of grants of

\footnotetext{
${ }^{7}$ Governments usually do not name individual defendants in price fixing cases for at least two reasons: to elicit cooperation and information, and to protect investigative methods. In addition, according to Prof. Connor, the author of our data source, sometimes litigation records are sealed by mutual consent of the parties and the court. To the best of our knowledge, the names of responsible executives are not reported in court documents even when these managers are not charged as defendants. We cross-checked a sample of our cases against case reports in the Commerce Clearing House (CCH) Reporter, which seems to be the data source for much of the information used in empirical antitrust research. We found no additional names of defendants in the CCH Reporter and no discrepancies with information in Connor's (2010) dataset. We also cross-checked about half of our cases against news and government databases such as Factiva, Lexis-Nexis, and SEC EDGAR. We generally found less information in these sources than exists in our data source.
} 
immunity resulting from leniency programs. In our sample, we have data on 31 prison sentences. They range from four months to 14 years with a mean (median) of 28.9 (26) months. Regulators appear to treat the managers of publicly traded companies with less leniency than the managers of private firms. A total of 1,680 public (including the 248 listed U.S. firms in our sample) and 868 private firms are identified by authorities as participants in the 327 cartels covered by our sample. For all of these observations (most of which are foreign and thus not covered by our sample), mean fines for public firms are significantly higher than fines for private cartel firms, $\$ 55.52$ million vs. $\$ 19.41$ million, with the difference being significant at the $1 \%$ level. The average incidence of imprisonment is $0.12(0.08)$ executives per cartel for public (private) firms, a difference that seems large but is statistically insignificant $(p=0.14)$. The significant difference in fines may be due to a larger stake of public firms in the cartels. Data on affected sales and estimated overcharges is, however, only estimated at the cartel and not the individual firm level. Hence, we cannot relate the fines to the effective stake a firm had in a cartel.

\section{Governance strategies for concealing price-fixing}

One reason that corporate managers appear to have little exposure to internal or government sanctions for price fixing may be that they actively conceal this behavior from their own monitors. In particular, managers could control access to information by the board of directors or outside auditors by not replacing the CEO as often (as shown above) and not bringing in external replacements from outside the firm when the CEO position does change hands. Similar dynamics could apply to membership of the board of directors and the rotation of auditors. We examine these hypotheses in the subsections below. 


\subsection{Internal selection of new CEOs}

When a cartel firm chooses a new CEO, we would expect that person to come from within the company rather than from outside. An outsider might halt and expose the price fixing conspiracy, potentially triggering sanctions for the company and the other managers.

In Table 7, we estimate probit models for whether a new CEO is selected internally, for those company-year observations (about $17.4 \%$ of the observations) in which a CEO replacement occurs. Control variables are identical to those in Table 6, with certain additions. The model in the second column includes the number of business segments as an additional control, and the model in the third column includes an indicator for family firms defined as in Anderson, Duru, and Reeb (2009) and Anderson, Reeb, and Zhao (2012). ${ }^{8}$ Both of these types of companies may have a higher incidence of internal promotions. The inclusion of these variables substantially reduces the sample size. In all three columns we obtain positive and significant estimates for the cartel firm indicator, consistent with these firms choosing their leaders internally. These results are confirmed by the within-firm analysis in Panel B where the During coefficient is significantly different from zero across all three columns. The ordinary rate of internal CEO promotions is about 78 percent in our sample, and the marginal effects of the estimates in the three columns are $0.083,0.101$, and 0.093 , respectively, implying that the rate of internal CEO promotions is more than 10 percent higher than usual in cartel firms.

\subsection{Replacement of directors}

Evading detection by monitors from inside and outside the firm must represent a primary goal of the managers of cartel firms. Regardless of whether current members of the board of

\footnotetext{
${ }^{8}$ Data on family firms is obtained from David Reeb and available only for the years 2001-2010.
} 
directors have knowledge of a cartel, we can make a straightforward prediction about changes in the board. Companies should be reluctant to replace directors who resign or retire, because recruiting a new monitor from outside the company creates a risk of the cartel being halted and/or exposed. Alternatively, if they replace a director, firms may appoint a board member with a lower monitoring capacity. Moreover, directors learning about the conspiracy may decide to leave the board quietly to evade potential legal consequences and reputational damage (Fahlenbrach, Low, and Stulz, 2017). Hence, we would expect director turnover that is higher than usual.

Table 8 presents an analysis of board turnover and changes in board size for our cartel firms compared to companies in the control sample. We collect data on individual directors from the ISS Directors database, and the limited coverage of this source causes a large reduction in our sample size. In addition to the indicator for cartel firms, our regressions include control variables for changes in firm size and annual abnormal stock performance estimated by the market model (following Yermack's (1996) study of board size changes), indicators for CEOs near retirement age and for recently appointed CEOs, and industry fixed effects. ${ }^{9}$ Rather than including year fixed effects, we use an indicator that equals one beginning in 2002, the first-year in which the Sarbanes-Oxley Act and other regulations required companies to begin implementing changes in board structure. However, our results in Table 8 are robust to replacing the Sarbanes-Oxley indicator with year indicators. The inclusion of industry fixed effects costs us some observations, because all cases in which there is no variation in the dependent variable within an industry are deleted by the probit econometric procedure. In addition to the expected negative associations between director turnover and stock returns, estimates in the first two

\footnotetext{
${ }^{9}$ In the first two columns of Table 8, we additionally include a classified board dummy variable. Like prior research on the topic (Faleye, 2007), we find no evidence of decreased director turnover on classified boards.
} 
columns of Table 8 show two patterns for cartel firms. Directors resign or retire more frequently in cartel firms compared to companies in the control sample, and when they leave, cartel firms are more likely to allow the board to shrink rather than to replace them. This latter result is only statistically significant in the within-firms analysis reported in Panel B. Both effects appear to have economic significance. The baseline rate of director turnover is about 9 percent and the estimate of 0.011 (0.015) for the cartel variable in Panel A (Panel B) of Table 8 indicates that turnover is 12 (17) percent higher than usual in cartel firms. The marginal effect for the probit estimate for cartel boards' probability of not replacing a director in Panel B is 0.029. Since the non-cartel firms have a mean of 28.3 percent, the propensity not to fill a vacant board seat increases by about 10 percent in cartel companies. Reasons for director resignations are not clear, but one possibility is that board members who become aware of wrongdoing leave quietly to evade future legal liability or to signal disagreement with management's actions (see Fahlenbrach, Low, and Stulz, 2017). The motive for cartel firms not to replace exiting directors seems plain: by leaving a board seat vacant, the company avoids the possibility of being monitored by a new individual from outside the firm.

Not all cartel firms' board vacancies are left unfilled, and columns 3 to 6 of Table 8 analyze the monitoring capacity of new outside directors appointed to the boards of cartel firms compared to new outside board appointees by companies in the control sample. Observations in columns 3 through 6 are restricted to the years in which new directors are appointed to cartel firm boards. We study new directors in two categories: those who reside in foreign countries and those who have social ties to the CEO. These types of directors have been shown in recent papers to perform poorly as monitors, due to such factors as distance, fatigue, and their unfamiliarity with U.S. accounting rules, as well as allegiance and personal ties to the CEO. 
In columns 3 and 4, we study the appointment of foreign directors. Foreign independent directors are the subject of a study by Masulis, Wang, and Xie (2012), who kindly shared their 1998-2006 sample with us. Although the dependent variable is a count variable, we use a binary probit dependent variable instead of a Poisson count data model since there are only three cases in which companies appoint more than one foreign director in the same year.

We estimate a Poisson maximum likelihood model of appointments of directors with social ties and the number of new social ties added to the board within a year in columns 5 and 6 , respectively. We follow Fracassi and Tate (2012), Engelberg, Gao, and Parsons (2013), and Fracassi (forthcoming) in defining social ties. We consider four types of ties. First, we define the $\mathrm{CEO}$ to be connected to a director in terms of current work experience if they work for the same firm, which is not the sample firm, at the time of the director's appointment. Second, we define the CEO to be connected to a director in terms of past work experience if they worked for the same company at the same time sometime in the past. Third, we define a CEO and director to have educational ties if the both graduated within one year from each other from the same school. ${ }^{10}$ Fourth, we define ties through social and other activities as follows: A director and CEO have social ties if they both served as board member, trustee, or in another leading function at a club, organization or charity (e.g., Business Roundtable, National Association of Manufacturers, Boy Scouts of America, etc.). We consider all four types of social ties by either defining an indicator whether a newly appointed director has any of these ties or by counting the total number of ties associated with newly appointed directors within the year. Observations in Columns 5 and 6 are restricted to the firms and period covered by the intersection of the ISS Directors and BoardEx databases (1999-2012).

\footnotetext{
${ }^{10}$ We use the narrowest definition provided in determining educational facilities (e.g., Harvard Law School and not Harvard University), as it is unlikely that people know each other across academic departments.
} 
To complement the analysis of the characteristics of individual board appointees, we estimate a Tobit regression model of the tenure-weighted co-option of the overall board in column 7. Co-option is defined following Coles, Daniel, and Naveen (2014) as the ratio of the cumulative years served by all independent directors appointed by the incumbent CEO divided by the cumulative tenure of all directors (CEO not included).

Along with the indicators for cartel firms, we use control variables similar to those used by Masulis, Wang, and Xie (2012) and Coles, Daniel, and Naveen (2008). These include the fraction of the firm's net sales made overseas (column 4), intangible assets / total assets, and an indicator that equals one if research \& development / total assets is in the $75^{\text {th }}$ percentile or higher in a given year on the Compustat database.

Estimates in Table 8 indicate that when appointing new directors, cartel firms are more likely to select outsiders with each of the attributes of foreign residence, social ties to the CEO, and co-option, consistent with a conjecture that management nominates new board members who are unlikely to monitor aggressively. In the probit models of foreign director appointments in columns 3 and 4 , one coefficient is significant at the $10 \%$ level and one is borderline insignificant in the cross-sectional analysis in Panel A, while the coefficients on both Before and During are significant at the 5\% level across both columns. Again, these effects appear to be economically large, with the marginal effects being 0.013 and 0.018 , respectively. The frequency for this type of director appointment in non-cartel firms is 1.5 percent. These data imply that the tendency of cartel firms to appoint foreign directors is about double compared to non-cartel firms. Incidence rate ratios in the Poisson regressions reported in columns 5-6 indicate that cartel firms on average appoint 44 percent more directors with ties to the CEO than control firms, and add on average 34 percent more additional CEO-ties to the board per year as 
compared to control firms. The mean ratio of the tenure of co-opted to the other directors in control firms is 18.1 percent. Results in column 7 suggest that this fraction is 1.8 percentage point (or about 10 percent) higher in cartel firms.

\subsection{Replacement of auditors}

We investigate cartel firms' changes in auditors to explore whether a pattern exists similar to that for boards of directors, with management exhibiting reluctance to bring in new outsiders who might monitor aggressively and become aware of the firm's illegal conduct. We use Compustat to identify changes in auditors and create an indicator that equals one for years in which the database reports a different auditor than the previous year. We restrict the sample to observations in which firms have a Big 4 auditor and change from one Big 4 auditing firm to another. Only 21 observations, or less than 1\%, of the cartel firm sample are associated with smaller auditing firms, and the fraction is significantly higher for firms in the control sample (4.3\%). Hence, firms in the control sample may be more likely to switch from smaller (or nonBig 4) to larger (Big 4) auditing firms, causing us to find a higher incidence of auditor switches of control firms. ${ }^{11}$ A limited number of auditing firms exit the industry due to mergers or liquidation (including, most famously, Arthur Andersen). In these cases, when an auditor change is mandatory and beyond the control of the firm, we set the auditor change indicator equal to missing.

In Panel A of Table 9, we report estimates for probit regressions of the auditor change indicator against the cartel indicator as well as a wide range of control variables used by Landsman, Nelson, and Rountree (2009) in their study of auditor replacement, as well as year

\footnotetext{
${ }^{11}$ In unreported tests we find that when we include all firm-years, whether the firm has a Big 4 auditor or not, the results become even stronger with $t$-statistics of the cartel indicator in Panel A and the During variable in Panel B being significant at the $1 \%$ level and larger than 3 across all three specifications.
} 
and industry fixed effects. The second column replaces a firm's absolute discretionary accruals from a Jones (1991) model by those from a modified Jones model (Dechow, Sloan, and Sweeney, 1995), as used in Klein (2002) and Bergstresser and Philippon (2006). The model in the third column replaces the accruals-based measures of earnings management by an indicator for years with financial restatements.

The coefficients on the cartel indicator are significant at the 5\% level or better across all three columns, suggesting that cartel firms change auditors less often than other companies. The results from the within-firm analysis in Panel B are similar, with the coefficient on the During variable being negative and significant at the $1 \%$ level across all three columns. The results in Table 9 are consistent with those found above documenting unusually slow replacement of directors and CEOs for cartel companies, and they suggest that management attempts to reduce external scrutiny by restricting the entry of new monitors. The estimated marginal effects for the cartel variable in Panel A indicate reduced replacement frequencies of $-0.014,-0.014$, and 0.015, respectively, while the estimated marginal effects for the During variable in Panel B indicate reduced replacement frequencies of $-0.011,-0.011$, and -0.012 , respectively.

\section{Conclusions}

We study the consequences of cartel participation for top corporate managers. Although a strong public interest exists against businesses fixing prices and reducing corporate output, our analysis suggests that this behavior is attractive to top managers of public companies. We study a comprehensive sample of firms sanctioned for cartel behavior and compare them with a control sample of firms matched on size and industry. The managers of cartel firms only infrequently face legal sanctions, and at the same time they enjoy greater job security and are able to extract 
high executive compensation by timing their stock options exercises with periods of cartel participation. Their compensation also appears to be less risky, with more of it delivered in the form of cash bonuses. These bonuses will be increased when cartel firms are able to increase profits by raising prices.

Managers of cartel firms may obtain these benefits partly by concealing their price fixing strategies from their boards of directors and auditors. We find a variety of evidence consistent with this hypothesis. When the CEO position becomes vacant, cartel firms are less likely to recruit an outside replacement. Board seats that open up are filled less frequently by cartel firms, and new directors tend to come from overseas or have greater external social ties with management. Auditor rotation occurs less frequently in cartel firms. 


\section{Appendix}

In this appendix, we test alternative procedures for drawing a control sample for the 248 cartel firms in our sample. The matching excludes four observations that enter the sample as spinoffs and inherit the control observations of the parent firm, so the potential number of cartel firms to be matched is 244 . We use four alternative matching procedures which are outlined in Panel A of Table A1. The base case matching approach, as used in the tables above, requires matching observations to come from the same two-digit SIC industry, and it then selects the five closest firms based on size. The first alternative approach, the size restriction method, requires all firms to have total assets within $+/-50 \%$ of the cartel firm and excludes 10 cartels for which no size match is within $+/-50 \%$. The second alternative approach, PS1, is a propensity score matching procedure that selects the five closest observations based on fitted values from a logit regression with the cartel indicator as dependent variable and the log of total assets, $\log$ of firm age, industry concentration ratio, return on assets, and year and industry fixed effects as explanatory variables. The third approach, PS2, is similar to PS1, but includes the number of business segments as additional control variable. Further we exclude cartels for which no potential matching observations fall within a caliper of 0.01 . Including the number of business segments and adding a propensity score restriction reduces the number of cartel firms to 212 . The fourth approach, PS3, is also similar to PS1, but it restricts the potential control observations to the same set of two-digit SIC industries as the cartel firm, though it does not require all matching to be done within industries.

In each row of Panel A in Table A1, we report how many of the 244 cartel firms remain in the analysis contingent on satisfying the matching criteria. The table also shows descriptive statistics about the size ratios between the cartel firms and their matched firms, using total assets 
as the measure of size. The size ratio compares the total assets of the cartel firm with the mean value of total assets for the matching firms, calculated as of the matching year. Test statistics in the table show that the size difference becomes insignificant in all three propensity score matching approaches.

Panel B of Table A1 summarizes the results of re-estimating the paper's regressions using the samples generated by the alternative matching procedures. The table shows whether the coefficient estimate for the cartel indicator in each column of every table has statistical significance at conventional levels. For all significant estimates in our base case, the signs of the coefficients are identical across the different samples. The table shows that the statistical significance of our estimates generally carries across the alternative matching approaches, with a relatively small number of exceptions. In many of the problematic models, such as analysis of the appointments of foreign directors (columns 3 and 4 of Table 8) and analysis of whether newly appointed CEOs are promoted from the inside (column 3 of Table 7), we are working with small samples sizes due to limited data availability of the foreign director and family firm variables. 


\section{References}

Amihud, Y., 2002, Illiquidity and stock returns: Cross-section and time-series effects. Journal of Financial Markets 5, 31-56.

Anderson, R.C., Duru, A., and D.M. Reeb, 2009, Founders, heirs, and corporate opacity in the United States. Journal of Financial Economics 92, 205-222.

Anderson, R.C., Reeb, D.M., and W. Zhao, 2012, Family-controlled firms and informed trading: Evidence from short sales. Journal of Finance 67, 351-385.

Bergstresser, D., and T. Philippon, 2006, CEO incentives and earnings management. Journal of Financial Economics 80, 511-529.

Bolotova, Y.V., 2009, Cartel overcharges: An empirical analysis. Journal of Economic Behavior and Organization 70, 321-341.

Campello, M., Ferrés, D., and G. Ormazabal, 2016, Whistleblowers on the board? The role of independent directors in cartel prosecutions. Unpublished manuscript, Cornell University.

Coles, J.L., Daniel, N.D., and L. Naveen, 2008, Boards: Does one size fit all? Journal of Financial Economics 87, 329-356.

Coles, J.L., Daniel, N.D., and L. Naveen, 2014, Co-opted boards. Review of Financial Studies $27,1751-1796$.

Connor, J.M., 2010, Recidivism revealed: Private international cartels 1990-2009. Competition Policy Journal 6, 101-127.

Connor, J.M., 2014, The private international cartel (PIC) data set: Guide and summary statistics, 1990-2013. Unpublished manuscript, Purdue University.

Connor, J.M., 2016, International cartel stats: A look at the last 26 years. Unpublished manuscript, Purdue University.

Connor, J.M., and C.G. Helmers, 2007, Statistics on modern private international cartels, 19902005. Unpublished manuscript, Purdue University.

Dechow, P., Sloan, R., and A. Sweeney, 1995, Detecting earnings management. Accounting Review 170, 193-225.

Dong, A., Massa, M., and A. Zaldokas, 2016, Busted! Now what? Effects of cartel enforcement on M\&A. Unpublished manuscript, INSEAD.

Engelberg, J., Gao, P., and C.A. Parsons, 2013, The price of a CEO's rolodex. Review of Financial Studies 26, 79-114. 
Fahlenbrach, R., Low, A., and R. Stulz, 2017, Do independent director departures predict future bad events? Review of Financial Studies 30, 2313-2358.

Faleye, O., 2007, Classified boards, firm value, and managerial entrenchment. Journal of Financial Economics 83, 501-529.

Fracassi, C., 2016, Corporate finance policies and social networks. Management Science 63, 2420-2438.

Fracassi, C., and G. Tate, 2012, External networking and internal firm governance. Journal of Finance 67, 153-194.

Harrington, J.E., 2006, How do cartels operate? Foundations and Trends in Microeconomics 2, $1-105$.

Jenter, D., and F. Kanaan, 2015, CEO turnover and relative performance evaluation. Journal of Finance 70, 2155-2184.

Jones, J., 1991, Earnings management during import relief investigations. Journal of Accounting Research 29, 193-228.

Kedia, S., and T. Philippon, 2009, The economics of fraudulent accounting. Review of Financial Studies 22, 2169-2199.

Klein, A., 2002, Audit committee, board of director characteristics, and earnings management. Journal of Accounting and Economics 33, 375-400.

Landsman, W.R., Nelson, K.K, and B.R. Rountree, 2009, Auditor switches in the pre- and postEnron eras: Risk or realignment? Accounting Review 84, 531-558.

Leone, A.J., Wu, J.S., and J.L. Zimmerman, 2006, Asymmetric sensitivity of CEO cash compensation to stock returns. Journal of Accounting and Economics 42, 167-192.

Levenstein M.C., and V.Y. Suslow, 2006, What determined cartel success? Journal of Economic Literature 44, 43-95.

Masulis, R.W., Wang, C., and F. Xie, 2012, Globalizing the boardroom - The effects of foreign directors on corporate governance and firm performance. Journal of Accounting and Economics $53,527-554$.

McCahery, J., Sautner, Z., and L. Starks, 2016, Behind the scenes: The corporate governance preferences of institutional investors. Journal of Finance 71, 2905-2932.

Parrino, R., Sias, R.W., and L.T. Starks, 2003, Voting with their feet: Institutional ownership changes around forced CEO turnover. Journal of Financial Economics 68, 3-46. 
Peters, F.S., and A.F. Wagner, 2014, The executive turnover risk premium. Journal of Finance 69, 1529-1563.

Shaw, K.W., and M.H. Zhang, 2010, Is CEO cash compensation punished for poor firm performance? Accounting Review 85, 1065-1093.

Shleifer, A., and R.W. Vishny, 1986, Large shareholders and corporate control. Journal of Political Economy 94, 461-488.

Yermack, D., 1996, Higher market valuation of companies with a small board of directors. Journal of Financial Economics 40, 185-211. 
Table 1

Summary statistics for observations in cartel sample and control sample

Panel A of the table shows descriptive statistics of financial variables for the cartel participants and a sample of control firms matched on industry and size, with variables measured during the year of matching. Cartel firms are obtained from John Connor's Private International Cartel dataset, and control firms are extracted from Compustat using a matching procedure. Financial statement data is obtained from

Compustat. Stock return data is obtained from the CRSP database. Sample sizes below the maximum number of observations are generally the result of the limited universes or sample periods of these databases. Panel B shows descriptive statistics of all variables used in the paper for the cartel participants and the same sample of control firms for the entire sample as it enters our multivariate analyses. Board of directors data is obtained from the ISS Directors database. Foreign independent directors are identified from the sample of Masulis, Wang, and Xie (2012). Social ties between CEOs and directors are identified in the BoardEx database. Auditor changes are identified in Compustat. CEOs' stock option exercise and bonus data are obtained from ExecuComp, which is also used to identify CEO changes. Data on forced CEO turnover is obtained from Peters and Wagner (2014) and Jenter and Kanaan (2015). Abnormal stock performance is the intercept from a market model regression calculated for each firm each year.

Panel A: Descriptive statistics for matching year

Firm size (log (MV of equity + BV of debt))

Return on assets

Book-to-market

Tobin's Q

Leverage

Intangible assets / total assets

Cash / total assets

Absolute discretionary accruals (modified Jones)

Average net debt issued / total assets, past three years

Average net equity issued / total assets, past three years

Cash constraint

Indicator for (R\&D / total assets) above $75^{\text {th }}$ percentile

Indicator for dividend reduction

Number of business segments

Foreign sales percentage
Cartel firms

Mean
8.771
0.085
0.532
1.804
0.641
0.129
0.107
0.112
0.014
0.006
0.022
0.287
0.136
2.693
0.246

Std.

8.9751 .789 Dev.

$\begin{array}{ll}8.975 & 1.789\end{array}$

$\begin{array}{ll}0.081 & 0.085\end{array}$

$\begin{array}{ll}0.483 & 0.783\end{array}$

$1.296 \quad 1.349$

$\begin{array}{ll}0.626 & 0.215\end{array}$

$\begin{array}{ll}0.054 & 0.167\end{array}$

$0.053 \quad 0.144$

$\begin{array}{ll}0.048 & 0.317\end{array}$

$\begin{array}{ll}0.004 & 0.044\end{array}$

$0.000 \quad 0.062$

$0.003 \quad 0.100$

$\begin{array}{ll}0.000 & 0.453\end{array}$

$0.000 \quad 0.344$

$2.000 \quad 1.707$

$0.233 \quad 0.215$

Obs.
213
244
213
213
243
216
244
184
167
155
168
244
198
215
205

Control firms

\begin{tabular}{lcrrcc} 
Mean & \multicolumn{2}{c}{ Median Std. Dev. } & Obs. & $\begin{array}{c}\text { Difference in } \\
\text { Means }\end{array}$ & p-value \\
8.359 & 8.390 & 1.773 & 938 & $0.412^{\mathrm{a}}$ & $(0.002)$ \\
0.080 & 0.078 & 0.096 & 1,061 & 0.005 & $(0.468)$ \\
0.550 & 0.527 & 1.029 & 937 & -0.019 & $(0.804)$ \\
1.672 & 1.267 & 1.290 & 938 & 0.131 & $(0.183)$ \\
0.652 & 0.646 & 0.260 & 1,077 & -0.011 & $(0.559)$ \\
0.120 & 0.041 & 0.170 & 955 & 0.008 & $(0.522)$ \\
0.111 & 0.058 & 0.143 & 1,082 & -0.005 & $(0.657)$ \\
0.148 & 0.052 & 1.042 & 822 & -0.036 & $(0.641)$ \\
0.016 & 0.006 & 0.061 & 710 & -0.002 & $(0.677)$ \\
0.008 & 0.000 & 0.064 & 706 & -0.003 & $(0.608)$ \\
0.025 & 0.005 & 0.107 & 742 & -0.003 & $(0.774)$ \\
0.290 & 0.000 & 0.454 & 1,083 & -0.003 & $(0.924)$ \\
0.181 & 0.000 & 0.386 & 904 & -0.045 & $(0.130)$ \\
2.364 & 2.000 & 1.579 & 960 & $0.329^{\text {a }}$ & $(0.007)$ \\
0.267 & 0.178 & 0.287 & 911 & -0.021 & $(0.325)$
\end{tabular}


Cartel firms

CEO value realized / intrinsic value of vested options CEO options exercised / number of vested options

Top 5 value realized / intrinsic value of vested options

Top 5 options exercised / number of vested options

Options outstanding

Tobin's Q

CEO bonus / total compensation

Top 5 bonus / total compensation

Firm size (ln (MV of equity + BV of debt)

Return on assets

Book-to-market

Return to shareholders

\section{Leverage}

Cash constraint

Average net debt issued / total assets, past three years

Average net equity issued / total assets, past three years

CEO tenure (years)

CEO age

$\%$ change in CEO share ownership

CEO turnover (indicator)

Forced CEO turnover (indicator)

Voluntary CEO turnover (indicator)

Dividend reduction (indicator)

Board composition (\% independent)

Abnormal stock performance

New CEO promoted internally (indicator)

Number of business segments

Family firm indicator

\begin{tabular}{|c|c|c|c|c|c|c|c|c|c|c|}
\hline & Cartel fir & $\mathrm{rms}$ & & & Control f & $\mathrm{rms}$ & & & & \\
\hline Mean & Median & $\begin{array}{r}\text { Std. } \\
\text { Dev. }\end{array}$ & Obs. & Mean & Median & $\begin{array}{r}\text { Std. } \\
\text { Dev. }\end{array}$ & Obs. & $\begin{array}{l}\text { Difference } \\
\text { in Means }\end{array}$ & & p-value \\
\hline 0.210 & 0.059 & 0.304 & 1,295 & 0.183 & 0.011 & 0.284 & 1,968 & 0.027 & $\mathrm{a}$ & $(0.010)$ \\
\hline 0.113 & 0.002 & 0.199 & 1,456 & 0.109 & 0.000 & 0.210 & 2,269 & 0.004 & & $(0.531)$ \\
\hline 0.252 & 0.152 & 0.281 & 1,380 & 0.223 & 0.131 & 0.265 & 2,128 & 0.029 & $\mathrm{a}$ & $(0.002)$ \\
\hline 0.132 & 0.067 & 0.175 & 1,488 & 0.124 & 0.050 & 0.182 & 2,365 & 0.007 & & $(0.209)$ \\
\hline 48.658 & 13.799 & 89.693 & 1,501 & 17.845 & 5.927 & 45.565 & 3,021 & 30.810 & $\mathrm{a}$ & $(0.000)$ \\
\hline 1.757 & 1.359 & 1.262 & 2,313 & 1.688 & 1.289 & 1.576 & 6,155 & 0.068 & $\mathrm{c}$ & $(0.061)$ \\
\hline 0.156 & 0.115 & 0.180 & 1,833 & 0.142 & 0.086 & 0.173 & 2,956 & 0.014 & $\mathrm{a}$ & $(0.007)$ \\
\hline 0.160 & 0.132 & 0.160 & 1,826 & 0.140 & 0.105 & 0.153 & 2,925 & 0.020 & $\mathrm{a}$ & $(0.000)$ \\
\hline 9.703 & 9.634 & 2.101 & 2,313 & 8.790 & 8.856 & 2.033 & 6,155 & 0.913 & $\mathrm{a}$ & $(0.000)$ \\
\hline 0.081 & 0.080 & 0.115 & 2,401 & 0.069 & 0.069 & 0.145 & 6,752 & 0.012 & $\mathrm{a}$ & $(0.000)$ \\
\hline 0.508 & 0.438 & 0.792 & 2,313 & 0.519 & 0.507 & 1.176 & 6,151 & -0.012 & & $(0.664)$ \\
\hline 2.419 & 0.050 & 74.542 & 2,280 & 1.281 & 0.041 & 44.584 & 6,178 & 1.138 & & $(0.392)$ \\
\hline 0.681 & 0.678 & 0.209 & 2,395 & 0.686 & 0.666 & 0.297 & 6,816 & -0.005 & & $(0.434)$ \\
\hline 0.020 & 0.005 & 0.109 & 1,937 & 0.026 & 0.005 & 0.165 & 5,456 & -0.006 & & $(0.163)$ \\
\hline 0.008 & 0.004 & 0.040 & 2,082 & 0.008 & 0.002 & 0.063 & 5,632 & -0.001 & & $(0.679)$ \\
\hline-0.008 & -0.002 & 0.052 & 1,942 & -0.003 & 0 & 0.049 & 5,598 & -0.005 & $\mathrm{a}$ & $(0.000)$ \\
\hline 7.214 & 5 & 6.448 & 1,777 & 6.968 & 5 & 6.620 & 2,839 & 0.246 & & $(0.214)$ \\
\hline 57.020 & 57 & 6.591 & 1,846 & 56.214 & 56 & 6.901 & 2,968 & 0.806 & a & $(0.000)$ \\
\hline 0.694 & 0.068 & 7.977 & 1,461 & 2.040 & 0.057 & 35.459 & 2,261 & -1.346 & & $(0.153)$ \\
\hline 0.130 & 0 & 0.337 & 1,679 & 0.189 & 0 & 0.392 & 2,754 & -0.059 & $\mathrm{a}$ & $(0.000)$ \\
\hline 0.022 & 0 & 0.147 & 1,679 & 0.034 & 0 & 0.182 & 2,754 & -0.012 & $\mathrm{~b}$ & $(0.021)$ \\
\hline 0.108 & 0 & 0.311 & 1,679 & 0.155 & 0 & 0.362 & 2,754 & -0.047 & $\mathrm{a}$ & $(0.000)$ \\
\hline 0.144 & 0 & 0.351 & 2,318 & 0.168 & 0 & 0.374 & 6,582 & -0.024 & $\mathrm{a}$ & $(0.006)$ \\
\hline 0.735 & 0.769 & 0.157 & 1,401 & 0.715 & 0.750 & 0.175 & 2,126 & 0.020 & $\mathrm{a}$ & $(0.000)$ \\
\hline 0.072 & 0.040 & 0.876 & 2,150 & 0.058 & 0.047 & 0.447 & 5,085 & 0.014 & & $(0.374)$ \\
\hline 0.874 & 1 & 0.332 & 207 & 0.776 & 1 & 0.418 & 406 & 0.099 & $\mathrm{a}$ & $(0.003)$ \\
\hline 2.973 & 3 & 1.877 & 1,933 & 2.436 & 2 & 1.596 & 5,877 & 0.537 & $\mathrm{a}$ & $(0.000)$ \\
\hline 0.232 & 0 & 0.422 & 823 & 0.252 & 0 & 0.435 & 1,462 & -0.020 & & $(0.279)$ \\
\hline
\end{tabular}


Fraction of directors leaving

Board becomes smaller (indicator)

New directors that are foreign and independent

Fraction of new directors with social ties to the CEO

Number of new social ties

Tenure-weighted co-option

CEO Age $>59$ (indicator)

CEO Tenure $<4$ (indicator)

Classified board (indicator)

(R\&D / total assets) above $75^{\text {th }}$ percentile (indicator)

Intangible assets / total assets

Foreign sales percentage

Auditor change (indicator)

Growth in total assets

ROA $<0$ (indicator)

(Inventory + receivables) / total assets

Auditor tenure

Cash / total assets

Acquisition (indicator)

Absolute discretionary accruals (Jones)

Absolute discretionary accruals (modified Jones)

Restatement (indicator)

Significant at $1 \%(\mathbf{a}), 5 \%(\mathbf{b})$ and $10 \%$ (c) levels.

\begin{tabular}{|c|c|c|c|c|c|c|c|c|c|}
\hline 0.089 & 0.083 & 0.102 & 1,299 & 0.086 & 0.083 & 0.099 & 1,864 & 0.002 & $(0.527)$ \\
\hline 0.301 & 0 & 0.459 & 1,300 & 0.283 & 0 & 0.451 & 1,936 & 0.018 & $(0.277)$ \\
\hline 0.029 & 0 & 0.169 & 444 & 0.015 & 0 & 0.123 & 650 & 0.014 & $(0.116)$ \\
\hline 0.246 & 0 & 0.552 & 357 & 0.153 & 0 & 0.386 & 430 & 0.093 & $(0.006)$ \\
\hline 0.375 & 0 & 0.756 & 357 & 0.244 & 0 & 0.586 & 430 & 0.131 & $(0.006)$ \\
\hline 0.194 & 0.099 & 0.242 & 1,235 & 0.181 & 0.070 & 0.243 & 1,781 & 0.013 & $(0.134)$ \\
\hline 0.332 & 0 & 0.471 & 1,851 & 0.313 & 0 & 0.464 & 2,992 & 0.019 & $(0.164)$ \\
\hline 0.414 & 0 & 0.493 & 1,851 & 0.442 & 0 & 0.497 & 2,992 & -0.028 & $(0.059)$ \\
\hline 0.451 & 0 & 0.498 & 1,670 & 0.595 & 1 & 0.491 & 2,504 & -0.145 & $(0.000)$ \\
\hline 0.239 & 0 & 0.427 & 2,414 & 0.239 & 0 & 0.426 & 6,915 & 0.000 & $(0.968)$ \\
\hline 0.138 & 0.066 & 0.166 & 2,176 & 0.125 & 0.044 & 0.169 & 6,276 & 0.014 & $(0.001)$ \\
\hline 0.295 & 0.320 & 0.227 & 1,867 & 0.282 & 0.244 & 0.281 & 5,413 & 0.013 & $(0.063)$ \\
\hline 0.022 & 0 & 0.147 & 2,230 & 0.039 & 0 & 0.194 & 6,194 & -0.017 & $(0.000)$ \\
\hline 0.133 & 0 & 0.572 & 2,315 & 0.132 & 0.053 & 2.174 & 6,750 & 0.001 & $(0.983)$ \\
\hline 0.058 & 0 & 0.234 & 2,366 & 0.093 & 0 & 0.290 & 6,748 & -0.034 & $(0.000)$ \\
\hline 0.313 & 0.285 & 0.182 & 2,272 & 0.307 & 0.267 & 0.206 & 6,603 & 0.006 & $(0.198)$ \\
\hline 11.080 & 10 & 7.427 & 2,322 & 9.538 & 8 & 6.442 & 6,635 & 1.542 & $(0.000)$ \\
\hline 0.104 & 0.063 & 0.120 & 2,404 & 0.117 & 0.068 & 0.142 & 6,885 & -0.013 & $(0.000)$ \\
\hline 0.063 & 0 & 0.244 & 2,102 & 0.062 & 0 & 0.241 & 6,201 & 0.001 & $(0.825)$ \\
\hline 0.222 & 0.053 & 0.941 & 1,769 & 0.184 & 0.050 & 0.754 & 5,142 & 0.037 & $(0.093)$ \\
\hline 0.226 & 0.055 & 0.985 & 1,769 & 0.186 & 0.052 & 0.784 & 5,142 & 0.040 & $(0.084)$ \\
\hline 0.043 & 0 & 0.203 & 2,414 & 0.036 & 0 & 0.187 & 6,915 & 0.007 & $(0.125)$ \\
\hline
\end{tabular}




\section{Table 2}

\section{Cartel descriptive statistics}

The table shows descriptive statistics for the 327 cartels and 248 cartel participants (resulting in 634 different firm-cartel involvements) covered by our sample. Panel A reports descriptive statistics for participants and duration at the cartel level. Firms per cartel counts the number of firms identified as participants by all antitrust authorities or courts involved in the cartel's prosecution. The number of participants in a single jurisdiction might be smaller. Some of the start and end dates are estimated by the data provider, as they were not publicly disclosed. In some cases, our sample only covers part of the cartel duration. In 23 out of the 327 cartels in our sample, at least one defendant is reported as "anonymous company," and we exclude these 23 cartels in calculating the fraction of public and private firms per cartel. Panel B reports the place of collusion and the eight most often named lead jurisdictions. "U.S. private" indicates cartels that are not indicted by the government but instead face private litigation, mostly by customers and competitors. Panel C provides an overview of the affected commerce, overcharges, and fines associated with the 327 cartels in our sample. Some of the fines are estimated based on other information disclosed by regulators. In some instances, due to leniency, nolo contendere, or cease-and-desist pleas, lower or even no fines are imposed.

\section{Panel A: Cartel-level descriptive statistics}

Firms per cartel

Cartel participations per firm

Duration of cartel (in years)

Public firms per cartel

Private firms per cartel

Fraction of public firms per cartel

Panel B: Place of collusion and top lead jurisdictions

Place of collusion

Number of cartels

Number of cartel firms

Lead jurisdiction

Number of cartels

Number of cartel firms

\section{Mean \\ 8.05 \\ 2.46 \\ 7.57 \\ 5.14 \\ 2.65}

0.73

Median
6
1
6
4
1
0.75

Eastern

Africa

8

9
Asia
24

Europe

14

18

U.S. European

U.S.

50

87 $\begin{array}{rr}\text { private } & \text { Commission } \\ 39 & 39\end{array}$

133
Std. Dev.

7.49

3.13

6.10

4.52

4.04

0.25
Min.
2
1
1
1
0
0.06

North

America

76

203

South

Korea

17

$\begin{array}{rr}\text { Max. } & \text { Observations } \\ 55 & 327 \\ 21 & 248 \\ 33 & 327 \\ 35 & 327 \\ 24 & 327 \\ 1 & 304\end{array}$

Western
Europe
98
172

Brazil

10
Spain

10

14

\section{7}

327

327

\section{4}

$\begin{array}{rr}\text { Oceania } & \text { Western } \\ 6 & \text { Europe } \\ 9 & 98 \\ & 172 \\ & \\ \text { Spain } & \text { Brazil } \\ 10 & 10 \\ 14 & 23\end{array}$

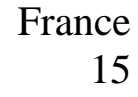

29 
Panel C: Fines

Affected commerce per cartel (\$ millions)

Overcharges per cartel (\$ millions)

Number of executives indicted per cartel

Number of executives indicted per cartel-firm

Worldwide fines per cartel-firm (\$ millions)
Mean

$6,577,671$

7,840

1.43

0.14

58.90

$\begin{array}{rr}\text { Median } & \text { Std. Dev. } \\ 4,450 & 51,969,873 \\ 438 & 31,455 \\ 0 & 4.97 \\ 0 & 0.72 \\ 4.62 & 211.44\end{array}$

Min.

Max. Observations

$0.08 \quad 642,590,000$

$0.03 \quad 245,604$

268

0

0

55

55
9

$0.00 \quad 2,679.00$

288

563

508 
Table 3

\section{Stock option exercises by CEOs and the top five named executives}

The table reports Tobit regression estimates for the value realized from options exercised over the intrinsic value of vested options (columns 1 and 3) and the number of options exercised over total vested options (columns 2 and 4). Panel A reports the results from pooled regressions of the option exercise variables on an indicator that equals one for years of cartel participation and controls. The sample includes all cartel firmyears of cartel firms and the matched control sample. Panel B reports results from estimating the regressions in Panel A with the cartel firm indicator replaced by three dummy variables indicating the time before the cartel, during the cartel, and after the cartel. The Before variable encompasses a five-year period starting seven years before and ending two years before the cartel conspiracy was determined to have started, and the variable After includes a five-year period after the end of the cartel, starting two years after the end of the cartel as determined by authorities. To account for uncertainty in the beginning and end dates of the cartel, we exclude the two years before and after the cartel. The sample in Panel B includes the Before, During, and After observations for all cartel firms as well as the complete history of matched control firms (as available for our sample period). Option exercise data is obtained from ExecuComp. Regressions include control variables for options outstanding, past stock performance, Tobin's Q and average industry exercises, which are calculated as the average value of the dependent variable for all firms in the same two-digit SIC industry with data available on ExecuComp in that year. All control variables are lagged by one year. $t$-statistics appear in parentheses.

Dependent variable:

Panel A: Cross-sectional tests Cartel firm indicator

Average industry exercises, prior year

Options outstanding x $10^{-2}$

Prior year stock return

Tobin's Q, prior year

\begin{tabular}{cc}
\multicolumn{2}{c}{ CEO only } \\
Value realized / & Options \\
intrinsic value of & exercised / \\
exercisable & exercisable \\
options & options
\end{tabular}

$\begin{array}{rr}0.058^{\mathrm{b}} & 0.034^{\mathrm{b}} \\ (2.493) & (2.133) \\ -0.194 & 0.029 \\ -1.145) & (0.175) \\ -0.027 & -0.044^{\mathrm{a}} \\ (-1.381) & (-3.356)^{\mathrm{a}} \\ 0.003^{\mathrm{b}} & 0.003^{\mathrm{a}} \\ (2.357) & (3.028) \\ 0.031^{\mathrm{a}} & 0.047^{\mathrm{a}} \\ (3.464) & (7.667)\end{array}$

Top five named executives

$\begin{array}{cc}\text { Value realized / } & \text { Options } \\ \text { intrinsic value of } & \text { exercised / } \\ \text { exercisable } & \text { exercisable } \\ \text { options } & \text { options }\end{array}$

$\begin{array}{rr}0.049^{\mathrm{a}} & 0.027^{\mathrm{a}} \\ (3.634) & (3.108)^{\mathrm{b}} \\ -0.258^{\mathrm{b}} & 0.204^{\mathrm{b}} \\ (-2.534) & (2.192)^{\mathrm{a}} \\ -0.004 & -0.029 \\ (-0.405) & (-4.785)^{\mathrm{a}} \\ 0.002^{\mathrm{b}} & 0.002^{\mathrm{a}} \\ (2.312) & (3.640)^{\mathrm{a}} \\ 0.025^{\mathrm{a}} & 0.037^{\mathrm{a}} \\ (4.799) & (10.763)\end{array}$




$\begin{array}{lrrrr}\text { Year fixed effects } & \text { Yes } & \text { Yes } & \text { Yes } & \text { Yes } \\ \text { Industry fixed effects } & \text { Yes } & \text { Yes } & \text { Yes } & \text { Yes } \\ \text { Firm-year observations } & 2,793 & 3,174 & 2,996 & 3,269 \\ \text { LR chi-squared } & 161.109 & 239.393 & 249.652 & 436.329 \\ \text { Prob. > chi-squared } & 0.000 & 0.000 & 0.000 & 0.000 \\ \text { Cartel firm-years } & 1,146 & 1,287 & 1,210 & 1,303 \\ \text { Control firm-years } & 1,647 & 1,887 & 1,786 & 1,966 \\ \text { Cartel firms } & 174 & 174 & 178 & 178 \\ \text { Control firms } & 285 & 294 & 289 & 296 \\ \text { Panel B: Within-firm } \text { analysis } & & & & \\ \text { Before } & -0.004 & 0.016 & -0.006 & 0.018 \\ & (-0.105) & (0.564) & (-0.295) & (1.191) \\ \text { During } & 0.061 & 0.033 & 0.037 & 0.017 \\ & (2.962) & (2.224) & (3.046) & (2.053) \\ \text { After } & 0.049 & 0.008 & 0.024 & -0.001 \\ & (1.574) & (0.337) & (1.314) & (-0.057) \\ \text { Control variables } & \text { Yes } & \text { Yes } & \text { Yes } & \text { Yes } \\ \text { Year fixed effects } & \text { Yes } & \text { Yes } & \text { Yes } & \text { Yes } \\ \text { Industry fixed effects } & \text { Yes } & \text { Yes } & \text { Yes } & \text { Yes } \\ \text { Firm-year observations } & 5,120 & 5,778 & 5,548 & 5,981 \\ \text { LR chi-squared } & 237.264 & 379.656 & 397.292 & 659.103 \\ \text { Prob. }>\text { chi-squared } & 0.000 & 0.000 & 0.000 & 0.000 \\ & & & & \end{array}$

Significant at $1 \%$ (a), 5\% (b) and 10\% (c) levels. 


\section{Table 4}

\section{Bonus compensation for CEOs and top 5 named executives}

The table reports Tobit regression estimates for the value of the CEO's (column 1 to 3 ) and the top five named executive officers' (column 4 to 6 ) annual bonuses as a fraction of their total compensation. Panel A reports the results from pooled regressions of annual bonus as a fraction of total compensation on a cartel indicator that equals one for years of cartel participation, along with a range of other control variables. The sample includes all cartel firmyears of cartel firms and the matched control sample. Panel B reports results from estimating the regressions in Panel A with the cartel firm indicator replaced by three dummy variables indicating the time before the cartel, during the cartel, and after the cartel. The Before variable encompasses a five-year period starting seven years before and ending two years before the cartel conspiracy was determined to have started and the variable After includes a five-year period after the end of the cartel, starting two years after the end of the cartel as determined by authorities. To account for uncertainty in the beginning and end dates of the cartel, we exclude the two years before and after the cartel. The sample in Panel B includes the Before, During, and After observations for all cartel firms as well as the complete history of matched control firms (as available for our sample period). Compensation data is obtained from ExecuComp. Control variables follow Leone, Wu, and Zimmerman (2006) and Shaw and Zhang (2010). Cash constraint equals dividends plus financial cash flow, minus operating cash flow, all divided by total assets. $z$-statistics appear in parentheses.

Dependent Variable:

Panel A: Cross-sectional tests Cartel firm indicator

Firm size (log of enterprise value)

Return on assets

Book-to-Market (*0.01)

Leverage

Shareholder return $(* 0.01)$

Cash constraint

Average net debt issued / total assets, past three years Average net equity issued / total assets, past three years

CEO Tenure

$\log$ (CEO age)

$\%$ change in CEO share ownership (*0.001)

Median $\ln (1+$ age $)$ Top5

execs.

Median change in shareholdings, Top5 execs.

high ROA

high Return
CEO bonus / Total compensation

\begin{tabular}{|c|c|c|c|c|c|c|c|c|c|c|}
\hline 0.018 & $\mathrm{~b}$ & 0.026 & b & 0.022 & $\mathrm{~b}$ & 0.027 & $\mathrm{a}$ & 0.027 & $\mathrm{a}$ & $0.026^{a}$ \\
\hline (2.077) & & $(2.510)$ & & $(2.211)$ & & $(4.351)$ & & (4.184) & & $(4.044)$ \\
\hline-0.003 & & -0.001 & & -0.003 & & -0.005 & $\mathrm{~b}$ & -0.003 & & -0.004 \\
\hline$(-1.000)$ & & $(-0.184)$ & & $(-0.726)$ & & $(-2.140)$ & & $(-1.140)$ & & $(-1.608)$ \\
\hline 0.557 & a & 0.541 & a & 1.379 & $\mathrm{a}$ & 0.298 & a & 0.278 & a & 0.236 \\
\hline$(8.804)$ & & $(7.455)$ & & $(3.503)$ & & $(6.732)$ & & $(6.045)$ & & $(0.975)$ \\
\hline-0.143 & & -0.445 & & -0.272 & & -0.637 & $\mathrm{~b}$ & -0.717 & b & -0.617 \\
\hline$(-0.303)$ & & $(-0.696)$ & & $(-0.408)$ & & $(-2.067)$ & & $(-2.244)$ & & $(-1.923)$ \\
\hline 0.041 & & 0.027 & & 0.069 & $\mathrm{~b}$ & 0.044 & $\mathrm{~b}$ & 0.040 & $\mathrm{~b}$ & 0.054 a \\
\hline (1.639) & & $(0.895)$ & & $(2.251)$ & & $(2.492)$ & & $(2.175)$ & & $(2.883)$ \\
\hline 0.021 & $\mathrm{a}$ & 0.315 & $\mathrm{a}$ & 10.647 & $\mathrm{~b}$ & 0.224 & $\mathrm{a}$ & 0.244 & $\mathrm{a}$ & 5.515 b \\
\hline (3.381) & & (3.393) & & $(2.527)$ & & $(3.530)$ & & (3.632) & & (2.112) \\
\hline 0.049 & & 0.095 & & 0.139 & $\mathrm{~b}$ & 0.013 & & -0.003 & & 0.019 \\
\hline (1.171) & & (1.528) & & $(2.253)$ & & $(0.395)$ & & $(-0.086)$ & & $(0.501)$ \\
\hline-0.115 & & -0.209 & $\mathrm{c}$ & -0.234 & c & -0.188 & a & -0.152 & $\mathrm{~b}$ & $-0.145 \mathrm{~b}$ \\
\hline$(-1.308)$ & & $(-1.715)$ & & $(-1.948)$ & & $(-2.994)$ & & $(-2.043)$ & & $(-1.972)$ \\
\hline 0.379 & $\mathrm{a}$ & 0.306 & $\mathrm{~b}$ & 0.197 & & 0.277 & a & 0.283 & $\mathrm{a}$ & 0.243 a \\
\hline \multirow[t]{15}{*}{ (3.146) } & & $(2.095)$ & & (1.378) & & $(3.294)$ & & (3.138) & & $(2.729)$ \\
\hline & & 0.001 & c & 0.001 & $\mathrm{c}$ & & & & & \\
\hline & & (1.657) & & (1.661) & & & & & & \\
\hline & & -0.016 & & -0.015 & & & & & & \\
\hline & & $(-0.340)$ & & $(-0.334)$ & & & & & & \\
\hline & & 0.125 & & 0.236 & & & & & & \\
\hline & & $(0.799)$ & & (1.483) & & & & & & \\
\hline & & & & & & & & 0.038 & & 0.039 \\
\hline & & & & & & & & (1.085) & & (1.112) \\
\hline & & & & & & & & -0.011 & & 0.004 \\
\hline & & & & & & & & $(-0.085)$ & & $(0.028)$ \\
\hline & & & & 0.073 & $\mathrm{a}$ & & & & & 0.008 \\
\hline & & & & $(3.024)$ & & & & & & $(0.507)$ \\
\hline & & & & 0.035 & a & & & & & 0.028 a \\
\hline & & & & $(3.247)$ & & & & & & (4.112) \\
\hline
\end{tabular}


ROA* high ROA

Return*high Return

Low ROA

Low Return

ROA*Low ROA

Return*Low Return

Year fixed effects

Industry fixed effects

Firm-year observations

LR chi-squared

Prob. > chi-squared

Cartel firm years

Control firm years

Cartel firms

Control firms

Panel B: Within-firm analysis

\section{Before}

During

After

Year fixed effects

Industry fixed effects

Firm-year observations

LR chi-squared

Prob. > chi-squared

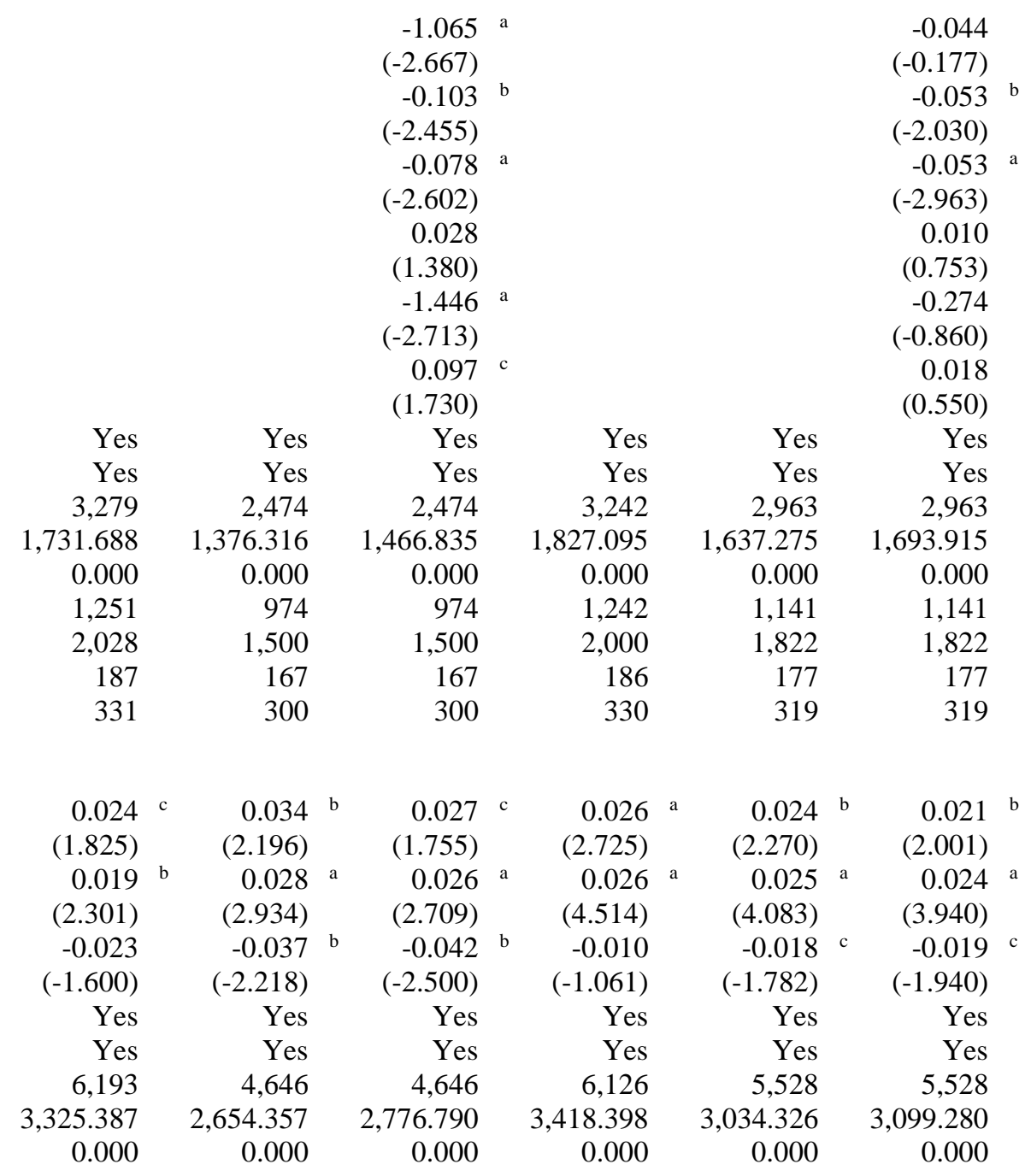

Significant at $1 \%(\mathbf{a}), 5 \%(\mathbf{b})$ and $10 \%$ (c) levels. 


\section{Table 5}

\section{Cross-sectional tests}

The table reports the results from tests of differences in means of variables related to stock option exercises and bonus compensation across subgroups of 634 cartel participations by our sample firms. For each cartel firm, we compute the mean, and alternatively the median, value of the output variables related to option exercises and bonus pay over the years of the cartel duration. The most left column shows cross-sectional sorting variables. To sort firms into terciles based on the percentage of institutional holdings and the Amihud (2002) illiquidity measure, we calculate mean values over the entire cartel period. We then perform a test for differences in means across the two groups. The number of observations is restricted by the availability of both the sorting variable and the output variable. $p$-values appear in parentheses.

\begin{tabular}{|c|c|c|c|c|c|c|c|c|c|c|c|c|c|c|c|c|c|c|c|c|}
\hline \multirow{2}{*}{$\begin{array}{l}\text { Output variable } \rightarrow \\
\text { Cross-sectional variable } \downarrow\end{array}$} & & \multicolumn{5}{|c|}{$\begin{array}{l}\text { Value realized / intrinsic value of } \\
\text { exercisable options - CEO }\end{array}$} & \multicolumn{4}{|c|}{$\begin{array}{l}\text { Value realized / intrinsic value } \\
\text { of exercisable options - Top five }\end{array}$} & \multicolumn{5}{|c|}{$\begin{array}{l}\text { Bonus / total compensation - } \\
\text { CEO }\end{array}$} & \multicolumn{5}{|c|}{$\begin{array}{c}\text { Bonus / total compensation - } \\
\text { Top five }\end{array}$} \\
\hline & & Mean & & Median & & Obs. & Mean & Median & & Obs. & Mean & & Median & & Obs. & Mean & & Median & & Obs. \\
\hline $\begin{array}{l}\text { Number of firms } \\
\text { participating in the cartel } \\
\text { (top tercile vs. rest) }\end{array}$ & $\begin{array}{l}\text { Difference in } \\
\text { (p-value) }\end{array}$ & $\begin{array}{r}0.057 \\
(0.004)\end{array}$ & a & $\begin{array}{r}0.078 \\
(0.001)\end{array}$ & a & 544 & $\begin{array}{r}0.033 \\
(0.043)\end{array}$ & $\begin{array}{r}0.045 \\
(0.010)\end{array}$ & b & 557 & $\begin{array}{r}0.022 \\
(0.053)\end{array}$ & c & $\begin{array}{r}0.032 \\
(0.013)\end{array}$ & b & 580 & $\begin{array}{r}0.035 \\
(0.001)\end{array}$ & a & $\begin{array}{r}0.048 \\
(0.000)\end{array}$ & a & 579 \\
\hline $\begin{array}{l}\text { Cartel in the US or global } \\
\text { vs. rest of the world }\end{array}$ & $\begin{array}{l}\text { Difference in } \\
\text { (p-value) }\end{array}$ & $\begin{array}{r}0.038 \\
(0.038)\end{array}$ & $\mathrm{b}$ & $\begin{array}{r}0.035 \\
(0.096)\end{array}$ & c & 544 & $\begin{array}{r}0.019 \\
(0.209)\end{array}$ & $\begin{array}{r}0.016 \\
(0.342)\end{array}$ & & 557 & $\begin{array}{r}0.025 \\
(0.017)\end{array}$ & $\mathrm{b}$ & $\begin{array}{r}0.030 \\
(0.012)\end{array}$ & b & 580 & $\begin{array}{r}0.043 \\
(0.000)\end{array}$ & a & $\begin{array}{r}0.046 \\
(0.000)\end{array}$ & a & 579 \\
\hline $\begin{array}{l}\text { No subsidiary vs. subsidiary } \\
\text { was penalized }\end{array}$ & $\begin{array}{l}\text { Difference in } \\
\text { (p-value) }\end{array}$ & $\begin{array}{r}0.043 \\
(0.017)\end{array}$ & b & $\begin{array}{r}0.039 \\
(0.058)\end{array}$ & c & 544 & $\begin{array}{r}0.015 \\
(0.310)\end{array}$ & $\begin{array}{r}0.015 \\
(0.358)\end{array}$ & & 557 & $\begin{array}{r}0.010 \\
(0.334)\end{array}$ & & $\begin{array}{r}0.012 \\
(0.331)\end{array}$ & & 580 & $\begin{array}{r}0.021 \\
(0.039)\end{array}$ & b & $\begin{array}{r}0.021 \\
(0.065)\end{array}$ & $\mathrm{c}$ & 579 \\
\hline $\begin{array}{l}\text { Institutional holdings (top } \\
\text { tercile vs. rest) }\end{array}$ & $\begin{array}{l}\text { Difference in } \\
\text { (p-value) }\end{array}$ & $\begin{array}{r}-0.050 \\
(0.008)\end{array}$ & a & $\begin{array}{r}-0.057 \\
(0.008)\end{array}$ & $\mathrm{a}$ & 485 & $\begin{array}{r}0.002 \\
(0.901)\end{array}$ & $\begin{array}{r}-0.010 \\
(0.563)\end{array}$ & & 493 & $\begin{array}{l}-0.055 \\
(0.000)\end{array}$ & a & $\begin{array}{l}-0.072 \\
(0.000)\end{array}$ & a & 514 & $\begin{array}{r}-0.046 \\
(0.000)\end{array}$ & a & $\begin{array}{l}-0.059 \\
(0.000)\end{array}$ & $\mathrm{a}$ & 513 \\
\hline $\begin{array}{l}\text { Amihud illiquidity measure } \\
\text { (top tercile vs. rest) }\end{array}$ & $\begin{array}{l}\text { Difference in } \\
\text { (p-value) }\end{array}$ & $\begin{array}{r}0.067 \\
(0.001)\end{array}$ & a & $\begin{array}{r}0.090 \\
(0.000)\end{array}$ & a & 554 & $\begin{array}{r}0.035 \text { b } \\
(0.031)\end{array}$ & $\begin{array}{r}0.042 \\
(0.018)\end{array}$ & $\mathrm{b}$ & 557 & $\begin{array}{r}0.035 \\
(0.002)\end{array}$ & a & $\begin{array}{r}0.042 \\
(0.002)\end{array}$ & a & 579 & $\begin{array}{r}0.025 \\
(0.026)\end{array}$ & $\mathrm{b}$ & $\begin{array}{r}0.026 \\
(0.035)\end{array}$ & $\mathrm{b}$ & 578 \\
\hline
\end{tabular}

Significant at $1 \%(\mathbf{a}), 5 \%(\mathbf{b})$ and $10 \%(\mathbf{c})$ 


\section{Table 6}

\section{CEO turnover}

The table shows probit regression estimates for models of CEO turnover. Panel A reports the results from pooled regressions of different CEO turnover variables on a cartel indicator that equals one for years of cartel participation and additional control variables. The sample includes all cartel firm-years of cartel firms and the matched control sample. The first column presents a model of CEO replacement with the dependent variable equal to one if a new CEO takes office. The second column presents estimates for a model in which the dependent variable equals one for forced CEO turnover and third column presents estimates for a model in which the dependent variable equals one for unforced CEO turnover. Data on forced CEO turnover is obtained from Peters and Wagner (2014) and Jenter and Kanaan (2015). Most control variables are based on Parrino, Sias, and Starks (2003). Panel B reports results from estimating the regressions in Panel A with the cartel firm indicator replaced by three dummy variables indicating the time before the cartel, during the cartel, and after the cartel. The Before variable encompasses a five-year period starting seven years before and ending two years before the cartel conspiracy was determined to have started and the variable After includes a five-year period after the end of the cartel, starting two years after the end of the cartel as determined by authorities. To account for uncertainty in the beginning and end dates of the cartel, we exclude the two years before and after the cartel. The sample in Panel B includes the Before, During, and After observations on all cartel firms as well as the complete history of matched control firms (as available for our sample period). $z$-statistics appear in parentheses. 
Dependent variable:

$\begin{array}{lcc}\begin{array}{c}\text { All CEO } \\ \text { turnover }\end{array} & \begin{array}{c}\text { Forced CEO } \\ \text { turnover }\end{array} & \begin{array}{c}\text { Unforced } \\ \text { CEO } \\ \text { turnover }\end{array}\end{array}$

Panel A: Cross-sectional tests

Cartel firm indicator

$\begin{array}{rrr}-0.207^{\mathrm{a}} & -0.295{ }^{\mathrm{b}} & -0.145^{\mathrm{c}} \\ (-2.882) & (-2.291) & (-1.888) \\ -0.020 & -0.638^{\mathrm{a}} & 0.184 \\ (-0.172) & (-3.089) & (1.520) \\ -0.096 & 0.284 & -0.228 \\ (-0.483) & (0.758) & (-1.097) \\ 0.001 & -0.012 & 0.003 \\ (0.108) & (-1.149) & (0.589) \\ -0.145 & -0.137 & -0.139 \\ (-1.540) & (-0.814) & (-1.370) \\ 0.052 & -0.523 & 0.269 \\ (0.232) & (-1.351) & (1.104) \\ -1.473 & -2.241 & -1.035 \\ (-3.193) & (-2.805) & (-2.106) \\ 0.058 & -0.002 & 0.068 \\ (10.717) & (-0.208) & (11.619) \\ 0.038 & 0.134 & \mathrm{a} \\ (1.415) & (2.767) & 0.010 \\ \text { Yes } & \text { Yes } & \text { a } \\ \text { Yes } & \text { Yes } & \text { Yes } \\ 3,027 & 2,587 & 3,027 \\ 0.091 & 0.078 & 0.116 \\ 1,261 & 1,071 & 1,261 \\ 1,766 & 1,516 & 1,766 \\ 165 & 145 & 165 \\ 283 & 251 & 283\end{array}$

Year fixed effects

Industry fixed effects

Firm-year observations

Pseudo $r$-squared

Cartel firm years

Control firm years

Cartel firms

Control firms

$\begin{array}{rrr}-0.239 \text { b } & -0.196 & -0.2311^{b} \\ (-2.197) & (-1.026) & (-1.961) \\ -0.130 \text { b } & -0.171 & -0.103 \\ (-2.068) & (-1.519) & (-1.543) \\ -0.118 & -0.062 & -0.116 \\ (-1.173) & (-0.363) & (-1.073) \\ \text { Yes } & \text { Yes } & \text { Yes } \\ \text { Yes } & \text { Yes } & \text { Yes } \\ \text { Yes } & \text { Yes } & \text { Yes } \\ 5,326 & 4,931 & 5,326 \\ 0.071 & 0.061 & 0.091\end{array}$

Panel B: Within-firm analysis

Before 


\section{Table 7}

\section{Internal selection of new CEOs}

The table shows probit regression estimates for models of whether a new CEO is promoted internally. Panel A reports the results from pooled regressions on a cartel indicator that equals one for years of cartel participation, along with a range of other control variables. The sample includes all cartel firm-years of cartel firms and the matched control sample but is restricted to those years in which a new CEO is appointed. Most control variables are based on Parrino, Sias, and Starks (2003). Family firms are identified based on Anderson, Duru, and Reeb (2009) and Anderson, Reeb, and Zhao (2012). Data on family firms is obtained from David Reeb and available for the years 2001-2010. Panel B reports results from estimating the regressions in Panel A with the cartel firm indicator replaced by three dummy variables indicating the time before the cartel, during the cartel, and after the cartel. The Before variable encompasses a five-year period starting seven years before and ending two years before the cartel conspiracy was determined to have started and the variable After includes a five-year period after the end of the cartel, starting two years after the end of the cartel as determined by authorities. To account for uncertainty in the beginning and end dates of the cartel, we exclude the two years before and after the cartel. The sample in Panel B includes the Before, During, and After observations for all cartel firms as well as the complete history of matched control firms (as available for our sample period). $z$-statistics appear in parentheses. 
Dependent variable:

Panel A: Cross-sectional analysis

Cartel firm indicator

CEO Tenure, as of prior year

Indicator for dividend reduction

Board composition (\% independent)

Return on assets, industry adjusted

Abnormal stock performance (prior year)

CEO age

Firm size (log of enterprise value)

Number of business segments

Family firm indicator

Year fixed effects

Industry fixed effects

Firm-year observations

Pseudo $r$-squared

Cartel firm-years

Control firm-years

Cartel firms

Control firms

Panel B: Within-firm analysis

Before

During

After

Control variables

Year fixed effects

Industry fixed effects

Firm-year observations

Pseudo $r$-squared

Significant at $1 \%$ (a), 5\% (b) and 10\% (c) levels.
0.148

(0.450)

New CEO promoted internally

$\begin{array}{rrr}0.513^{\mathrm{b}} & 0.776^{\mathrm{b}} & 0.615^{\mathrm{c}} \\ (2.151) & (2.458) & (1.765) \\ 0.034^{\mathrm{c}} & 0.026 & 0.054^{\mathrm{c}} \\ (1.780) & (1.137) & (1.726) \\ 0.259 & 0.626 & -0.058 \\ (0.904) & (1.485) & (-0.136) \\ -1.644 \mathrm{~b} & -1.259 & -2.9744^{\mathrm{b}} \\ (-2.127) & (-1.361) & (-2.396) \\ -0.677 & -0.558 & -0.751 \\ (-0.695) & (-0.469) & (-0.611) \\ 0.400 & 0.307 & 0.398 \\ (1.380) & (0.881) & (0.898) \\ 0.595 & 0.977 \mathrm{a} & 0.665 \\ (3.002) & (3.756) & (2.523) \\ 0.101 & 0.134 & 0.154 \\ (1.343) & (1.400) & (1.430) \\ & -0.150 \mathrm{c} & \\ & (-1.746) & \\ & & -0.468 \\ \text { Yes } & \text { Yes } & (-1.138) \\ \text { Yes } & \text { Yes } & \text { Yes } \\ 365 & 286 & 207 \\ 0.180 & 0.239 & 0.234 \\ 140 & 102 & 75 \\ 225 & 184 & 132 \\ 101 & 78 & 61 \\ 163 & 135 & \end{array}$

$0.554^{\mathrm{a}}$

(2.646)

0.376

(1.225)

Yes

Yes

Yes

594

0.140

$0.915^{\circ}$

0.360

(1.703)

(0.588)

$0.730^{\mathrm{a}}$

$0.574^{\mathrm{c}}$

(2.872)

(1.919)

0.248

0.176

(0.751)

(0.398)

Yes

Yes

Yes

Yes

Yes

302

467

0.176 


\section{Table 8}

\section{Retention, replacement, and characteristics of directors}

The table shows regression estimates of changes in firms' boards of directors. Panel A reports the results from pooled regressions of different board variables on an indicator that equals one for years of cartel participation and additional control variables. The sample includes all cartel firm-years of cartel firms and the matched control sample. Panel B reports results from estimating the regressions in Panel A with the cartel firm indicator replaced by three dummy variables. The Before variable encompasses a five-year period starting seven years before and ending two years before the cartel conspiracy, and the variable After includes a five-year period starting two years after the end of the cartel as determined by authorities. To account for uncertainty in the beginning and end dates of the cartel, we exclude the two years before and after the cartel. The sample in Panel B includes the Before, During, and After observations for all cartel firms as well as the complete history of matched control firms as available for our sample period. The first column reports results from a Tobit regression of the percentage of directors leaving the board in a given year. The second column reports results from a probit regression in which the dependent variable equals one if board size decreases in a given year. Column 3 and 4 present estimates of models of the probability that new outside board members are foreign. Column 5 presents estimates of models of the probability that new outside board members have social ties with the CEO. Column 6 reports results from a Poisson regression in which the dependent variable is the number of new social ties for directors joining the board. Social ties are defined following Fracassi and Tate (2012), Engelberg, Gao, and Parsons (2013), Fracassi (forthcoming). Column 7 reports on results of a Tobit regression with Coles, Daniel and Naveen's (2014) measure of tenure-weighted co-option. Control variables include the change in firm size based on the market value of equity plus the book value of debt. Abnormal stock performance is the intercept from a standard market model regression estimated for each company each year. The Sarbanes-Oxley indicator equals one for the years after enactment of the Sarbanes-Oxley Act (2002 and after). Controls for research \& development and intangible assets are defined as in Coles, Daniel, and Naveen (2008). $t$-statistics clustered at the firm level (columns 1 and 7) and z-statistics (columns 2 to 6) appear in parentheses. 
Dependent variable:

\begin{tabular}{|c|c|c|c|c|c|c|}
\hline $\begin{array}{c}\text { Fraction of } \\
\text { directors } \\
\text { leaving } \\
\text { (Tobit) }\end{array}$ & $\begin{array}{c}\text { Board } \\
\text { becomes } \\
\text { smaller } \\
\text { (Probit) }\end{array}$ & $\begin{array}{c}\text { New foreign } \\
\text { directors }\end{array}$ & $\begin{array}{c}\text { New foreign } \\
\text { directors }\end{array}$ & $\begin{array}{c}\text { Fraction of } \\
\text { new directors } \\
\text { with social } \\
\text { ties } \\
\text { (Poisson) }\end{array}$ & $\begin{array}{c}\text { Number of } \\
\text { new social } \\
\text { ties } \\
\text { (Poisson) }\end{array}$ & $\begin{array}{c}\text { Tenure- } \\
\text { weighted } \\
\text { co-option } \\
\text { (Tobit) }\end{array}$ \\
\hline $\begin{array}{r}0.0111^{\mathrm{c}} \\
(1.708) \\
0.004 \\
(0.337)\end{array}$ & $\begin{array}{r}0.027 \\
(0.502) \\
-0.265 \\
(-2.408)\end{array}$ & $\begin{array}{r}0.373^{\mathrm{c}} \\
(1.681) \\
0.119 \\
(0.263)\end{array}$ & $\begin{array}{r}0.356 \\
(1.484) \\
0.210 \\
(0.440)\end{array}$ & $\begin{array}{c}0.3655^{\mathrm{c}} \\
(1.946) \\
0.848 \\
(1.995)\end{array}$ & $\begin{array}{r}0.294^{\mathrm{c}} \\
(1.938) \\
1.200)^{\mathrm{a}} \\
(3.418)\end{array}$ & $\begin{array}{r}0.018 \text { b } \\
(2.424)\end{array}$ \\
\hline $\begin{array}{r}-0.040^{\mathrm{a}} \\
(-3.470) \\
-0.024^{\mathrm{b}} \\
(-2.376)\end{array}$ & $\begin{array}{r}-0.191 \quad b \\
(-2.161) \\
-0.198 \text { b } \\
(-2.410)\end{array}$ & $\begin{array}{r}-0.683 \\
(-1.783) \\
-0.716 \\
(-2.081)\end{array}$ & $\begin{array}{r}-0.588 \\
(-1.487) \\
-0.706 \text { b } \\
(-1.983)\end{array}$ & $\begin{array}{r}-0.399 \\
(-1.317) \\
0.355 \\
(1.369)\end{array}$ & $\begin{array}{r}-0.4233^{\mathrm{c}} \\
(-1.682) \\
0.287 \\
(1.353)\end{array}$ & $\begin{array}{r}0.007 \\
(0.673) \\
-0.003 \\
(-0.316)\end{array}$ \\
\hline $\begin{array}{r}0.003 \\
(0.361) \\
0.016 \text { b } \\
(2.324)\end{array}$ & $\begin{array}{r}-0.070 \\
(-1.236) \\
0.126 \\
(2.347)\end{array}$ & $\begin{array}{r}0.556 \mathrm{~b} \\
(2.370) \\
-0.158 \\
(-0.656)\end{array}$ & $\begin{array}{r}0.570 \mathrm{~b} \\
(2.333) \\
-0.184 \\
(-0.740)\end{array}$ & $\begin{array}{r}0.280 \\
(1.439) \\
0.020 \\
(0.105)\end{array}$ & $\begin{array}{r}0.496 \\
(3.184) \\
0.038 \\
(0.248)\end{array}$ & \\
\hline \multirow[t]{3}{*}{$\begin{array}{r}0.006 \\
(0.963)\end{array}$} & $\begin{array}{r}-0.151 \\
(-2.762) \\
-0.013 \\
(-0.241)\end{array}$ & $\begin{array}{r}-0.192 \\
(-0.835)\end{array}$ & $\begin{array}{r}-0.237 \\
(-0.938)\end{array}$ & $\begin{array}{r}-0.088 \\
(-0.382)\end{array}$ & $\begin{array}{r}-0.405{ }^{\mathrm{b}} \\
(-2.391)\end{array}$ & \\
\hline & & $\begin{array}{r}0.372 \\
(1.543) \\
1.347 \\
(1.484)\end{array}$ & $\begin{array}{r}0.229 \\
(0.903) \\
1.287 \\
(1.293) \\
0.515 \\
(0.856)\end{array}$ & $\begin{array}{r}0.199 \\
(0.745) \\
0.965 \\
(1.497)\end{array}$ & $\begin{array}{r}0.210 \\
(0.997) \\
1.040 \mathrm{~b} \\
(1.985)\end{array}$ & $\begin{array}{r}-0.010 \\
(-1.012) \\
0.059 \\
(2.003)\end{array}$ \\
\hline & & & & & & $\begin{array}{r}-0.015 \\
(-5.022)\end{array}$ \\
\hline
\end{tabular}


Board composition (\%

independent)

log (CEO age)

$\log$ (CEO tenure)

Year fixed effects

Industry fixed effects

Firm-year observations

Pseudo $r$-squared

LR chi-squared

Prob. > chi-squared

Cartel firm-years

Control firm-years

Cartel firms

Control firms

Panel B: Within-firm analysis

Before

During

After

Control variables

Year fixed effects

Industry fixed effects

Firm-year observations

Pseudo $r$-squared

LR chi-squared

Prob. > chi-squared

$\begin{array}{rr}\text { No } & \text { No } \\ \text { Yes } & \text { Yes } \\ 2,634 & 2,736 \\ & 0.018 \\ 77.741 & \\ 0.000 & \\ 1,140 & 1,160 \\ 1,494 & 1,576 \\ 161 & 163 \\ 259 & 272\end{array}$

No
Yes
797
0.150


346
451
106
157

No
Yes
563
0.130

No
Yes
714
0.064

No
Yes
714
0.096

$$
\begin{gathered}
-0.062^{\mathrm{c}} \\
(-1.888) \\
0.364^{\mathrm{a}} \\
(57.579) \\
0.416^{\mathrm{a}} \\
(15.613) \\
\text { Yes } \\
\text { Yes } \\
2,545
\end{gathered}
$$

3,151.068

0.000

1,069

1,476

\begin{tabular}{|c|c|}
\hline$(-0.519)$ & $(-0.007)$ \\
\hline $\begin{array}{r}0.015 \text { b } \\
(2.459)\end{array}$ & $\begin{array}{r}0.085 \\
(1.796)\end{array}$ \\
\hline
\end{tabular}

162

263

$-0.006 \quad-0.001$

$\begin{array}{rr}0.5733^{\mathrm{b}} & 0.609 \mathrm{~b} \\ (2.415) & (2.162) \\ 0.351^{\mathrm{b}} & 0.385 \mathrm{~b} \\ (1.976) & (1.992) \\ -0.100 & -0.154 \\ (-0.233) & (-0.343) \\ \text { Yes } & \text { Yes } \\ \text { No } & \text { No } \\ \text { Yes } & \text { Yes } \\ 1,309 & 955 \\ 0.086 & 0.096\end{array}$
0.252
(0.809)

\subsection{8}

$0.064^{\mathrm{a}}$

(1.286)

$0.320 \mathrm{~b}$

$0.310^{\mathrm{b}}$

(4.790)

$\begin{array}{r}0.048 \\ \hline\end{array}$

$-0.023$

0.009

(0.167)

(-0.094)

(0.014)

(0.312)

Yes

Yes

No

Yes

1,182

0.040

(1.251)

$-0.019$

(-1.618)

Yes

Yes

Yes

4,314

Yes
4,517

4,670
0.013

88.967

0.000
No
Yes
1,182
0.060

Significant at $1 \%$ (a), 5\% (b) and 10\% (c) levels. 


\section{Table 9}

\section{Changes in auditors}

The table reports the results from probit regressions of an indicator that equals one when the firm changes auditors in a given year. Panel A reports the results from pooled regressions of the auditor change indicator on an indicator that equals one for years of cartel participation and additional control variables. The sample includes all cartel firm-years of cartel firms and the matched control sample. Panel B reports results from estimating the regressions in Panel A with the cartel firm indicator replaced by three dummy variables indicating the time before the cartel, during the cartel, and after the cartel. The Before variable encompasses a five-year period starting seven years before and ending two years before the cartel conspiracy was determined to have started and the variable After includes a five-year period after the end of the cartel, starting two years after the end of the cartel as determined by authorities. To account for uncertainty in the beginning and end dates of the cartel, we exclude the two years before and after the cartel. The sample in Panel B includes the Before, During, and After observations for all cartel firms as well as the complete history of matched control firms (as available for our sample period). Auditor changes are identified from Compustat. The sample excludes a small number of observations for firms that do not have Big 4 auditors. All income statement and balance sheet variables are measured with respect to the prior fiscal year, and the definitions of control variables follow those used by Landsman, Nelson and Rountree (2009). $z$-statistics appear in parentheses. 
Dependent Variable:

Panel A: Cross-sectional tests

Cartel firm indicator

Growth in total assets

Return on assets $<0$ (indicator)

(Inventory + receivables) $/$ total assets

Auditor Tenure

Cash / total assets

Leverage

Return on assets

Firm size (log of enterprise value)

Acquisition (indicator)

Absolute discretionary accruals (Jones)

Absolute discretionary accruals (Modified Jones)

Restatement (indicator)

Year fixed effects

Industry fixed effects

Firm-year observations

Pseudo $r$-squared

Cartel firm-years

Control firm-years

Cartel firms

Control firms

Panel B: Within-firm analysis

Before

During

After

Control variables

Year fixed effects

Industry fixed effects

Firm-year observations
Company changes auditor $(0,1)$

\begin{tabular}{|c|c|c|}
\hline-0278 & $270 \quad$ a & \\
\hline$(-2.754)$ & $(-2.762)$ & $(-2.560)$ \\
\hline 0.175 & 0.174 & -0.122 \\
\hline$(2.396)$ & (2.393) & $(-0.654)$ \\
\hline-0.064 & -0.064 & -0.242 \\
\hline$(-0.416)$ & $(-0.417)$ & $(-1.183)$ \\
\hline-0.045 & -0.050 & 0.238 \\
\hline$(-0.122)$ & $(-0.135)$ & (0.642) \\
\hline-0.022 a & $-0.022^{a}$ & $-0.017^{b}$ \\
\hline$(-3.273)$ & $(-3.285)$ & $(-2.465)$ \\
\hline 0.266 & 0.259 & 0.269 \\
\hline$(0.778)$ & (0.757) & (0.668) \\
\hline 0.250 & 0.249 & 0.219 \\
\hline$(1.642)$ & (1.637) & (1.138) \\
\hline 0.037 & 0.035 & -0.537 \\
\hline$(0.145)$ & (0.139) & $(-0.939)$ \\
\hline$-0.052^{c}$ & $-0.051^{c}$ & -0.032 \\
\hline$(-1.888)$ & $(-1.854)$ & $(-1.026)$ \\
\hline-0.274 & $-0.276^{c}$ & -0.129 \\
\hline$(-1.642)$ & $(-1.657)$ & $(-0.591)$ \\
\hline \multirow{2}{*}{\multicolumn{3}{|c|}{$\begin{array}{r}0.008 \\
(0.064)\end{array}$}} \\
\hline & & \\
\hline \multirow{2}{*}{\multicolumn{3}{|c|}{$\begin{array}{r}0.051 \\
(0.441)\end{array}$}} \\
\hline & & \\
\hline & & $\begin{array}{r}0.540 \\
(3.449)^{\mathrm{a}}\end{array}$ \\
\hline Yes & Yes & Yes \\
\hline Yes & Yes & Yes \\
\hline 4,381 & 4,381 & 3,256 \\
\hline 0.120 & 0.120 & 0.089 \\
\hline 1,177 & 1,177 & 962 \\
\hline 3,204 & 3,204 & 2,294 \\
\hline 160 & 160 & 143 \\
\hline 479 & 479 & 376 \\
\hline-0.075 & -0.076 & 0.005 \\
\hline$(-0.557)$ & $(-0.558)$ & $(0.021)$ \\
\hline-0.240 & $-0.240^{a}$ & $-0.265 b$ \\
\hline$(-2.586)$ & $(-2.587)$ & $(-2.409)$ \\
\hline 0.048 & 0.049 & 0.099 \\
\hline$(0.332)$ & $(0.337)$ & $(0.642)$ \\
\hline Yes & Yes & Yes \\
\hline Yes & Yes & Yes \\
\hline Yes & Yes & Yes \\
\hline 11,268 & 11,268 & 7,032 \\
\hline
\end{tabular}


Significant at $1 \%(\mathbf{a}), 5 \%(\mathbf{b})$ and $10 \%$ (c) levels. 


\section{Table A1}

\section{Robustness tests}

The table shows the effects of alternative procedures for drawing a control sample for the 248 cartel firms in the paper. The matching excludes four observations that enter the sample as spinoffs and inherit the control observations of the parent firm, so the potential number of cartel firms to be matched is 244. Panel A describes the method used to construct the control sample for our base case matching procedure as used in the tables above, along with the methods for four alternative matching procedures. In each row, the table shows how many of the 244 cartel firms remain in the analysis contingent on satisfying the matching criteria. The table also shows descriptive statistics about the size ratios between the cartel firms and their matched firms, using total assets as the measure of size. In each case, the size ratio compares the total assets of the cartel firm with the mean value of total assets for the matching firms, calculated as of the matching year. In the last two columns, we report the difference in mean size, as measured by the log of total assets, along with the $p$-value for a difference in means test across the cartel firms and control samples as of the matching year. The base case matching approach requires matching observations to come from the same two-digit SIC industry, and it then selects the five closest firms based on size. The size restriction method requires all firms to have total assets within $+/-50 \%$ of the cartel firm and excludes 10 cartels for which no size match is within $+/-50 \%$. PS1 is a propensity score matching procedure that selects the five closest observations based on fitted values from a logit regression with the cartel indicator as the dependent variable and the log of total assets, log of firm age, industry concentration ratio, return on assets, and year and industry fixed effects as explanatory variables. PS2 is similar to PS1, but includes the number of business segments as additional control variable. Further we exclude cartels for which no potential matching observations fall within a caliper of 0.01. Including the number of business segments and adding a propensity score restriction reduces the number of cartel firms to 212. PS3 is similar to PS1, but it restricts the potential control observations to the same set of two-digit SIC industries as the cartel firm, though it does not require all matching to be done within industries. Panel B shows the results of re-estimating the paper's regressions using the samples generated by the alternative matching procedures. The table shows whether the coefficient estimate for the cartel indicator in each column of every table has statistical significance at conventional levels. For all significant estimates the signs of the coefficients are identical across the different samples. 
Panel A: matching method

Type of match Description of method

(1) Base case

Matched on industry and the five closest firms based on size

(2) Size restriction Matched on industry and the five closest firms based 234 on size, but only those with difference of less than $50 \%$

(3) PS1

(4) PS2

(5) PS3
Use the 5 closest firms based on propensity score

244

Includes number of business segments in the regression. Drop any firm for which no match is within caliper of 0.01 is found

Use the 5 closest firms based on propensity score with all matching observations drawn from the same industry as cartel firms

212

244
Cartel Size ratio based on total assets Diff. in $p$ -

firms Mean Median Std. Min. Max $\ln (\mathrm{TA})$ value

244

$1.45 \quad 1.05$

$1.58 \quad 0.74$

21.72

$-0.318 * *(0.037)$

$1.07 \quad 1.02$

$\begin{array}{llll}0.19 & 0.54 & 2.00 & -0.254\end{array}$

$(0.051)$

$1.88 \quad 0.58$

$\begin{array}{llll}5.75 & 0.00 & 79.01 & -0.144\end{array}$

$1.74 \quad 0.45$

$\begin{array}{llll}4.04 & 0.00 & 33.54 & -0.179\end{array}$

$1.20 \quad 0.84$

$\begin{array}{llll}1.20 & 0.00 & 8.65 & -0.025\end{array}$

(0.863) 
Panel B: statistical significance of coefficient estimates for cartel indicator

\begin{tabular}{|c|c|c|c|c|c|c|c|c|c|c|c|c|c|}
\hline & \multicolumn{4}{|c|}{ Table 3} & \multicolumn{6}{|c|}{ Table 4} & \multicolumn{3}{|c|}{ Table 6} \\
\hline & c1 & $\mathrm{c} 2$ & c3 & c4 & $\mathrm{c} 1$ & c2 & c3 & $\mathrm{c} 4$ & $c 5$ & c6 & $\mathrm{c} 1$ & $\mathrm{c} 2$ & $\mathrm{c} 3$ \\
\hline (1) & $* *$ & $* *$ & $* * *$ & $* * *$ & $* *$ & $* *$ & $* *$ & $* * *$ & $* * *$ & $* * *$ & $* * *$ & $* *$ & $*$ \\
\hline (2) & $* *$ & $* *$ & $* * *$ & $* * *$ & $* *$ & $* *$ & $* *$ & $* * *$ & $* * *$ & $* * *$ & $* * *$ & $* *$ & $* *$ \\
\hline (3) & $* *$ & $*$ & $* *$ & & $* *$ & $* *$ & $* *$ & $* * *$ & $* * *$ & $* * *$ & $*$ & & $*$ \\
\hline (4) & $* * *$ & $* * *$ & $* * *$ & $* * *$ & $* * *$ & $* * *$ & $* * *$ & $* * *$ & $* * *$ & $* * *$ & $* * *$ & & $* *$ \\
\hline (5) & & $* *$ & $*$ & $* * *$ & $* * *$ & $* * *$ & $* *$ & $* * *$ & $* * *$ & $* * *$ & $* * *$ & & * \\
\hline
\end{tabular}

\begin{tabular}{|c|c|c|c|c|c|c|c|c|c|c|c|c|c|}
\hline & \multicolumn{3}{|c|}{ Table 7} & \multicolumn{7}{|c|}{ Table 8} & \multicolumn{3}{|c|}{ Table 9} \\
\hline & $\mathrm{c} 1$ & $\mathrm{c} 2$ & $\mathrm{c} 3$ & $\mathrm{c} 1$ & $\mathrm{c} 2$ & $\mathrm{c} 3$ & $\mathrm{c} 4$ & $\mathrm{c} 5$ & c6 & c7 & $\mathrm{c} 1$ & c2 & c3 \\
\hline (1) & $* *$ & $* *$ & $*$ & $*$ & & $*$ & & $*$ & $*$ & $* *$ & $* * *$ & $* * *$ & $* *$ \\
\hline (2) & $* *$ & $* *$ & $*$ & & & & & $* *$ & $* *$ & $* *$ & $* * *$ & $* * *$ & $* *$ \\
\hline (3) & & $* *$ & & & $* *$ & & & $*$ & & $*$ & $* * *$ & $* * *$ & $* *$ \\
\hline (4) & $* *$ & $* * *$ & & & & & & $* *$ & $* *$ & $* * *$ & $* *$ & $* *$ & $* * *$ \\
\hline (5) & $*$ & & & $* *$ & & $*$ & $*$ & & & $* * *$ & $* *$ & $* *$ & $* * *$ \\
\hline
\end{tabular}

$* * *, * *$, and $*$ indicate statistical significance of regression estimates at the $1 \%, 5 \%$, and $10 \%$ levels, respectively. 